\title{
THE EVOLUTION OF INTERNATIONAL INVESTMENT LAW AND ITS APPLICATION TO THE ENERGY SECTOR
}

\author{
ELIZABETH WHITSITT* AND NIGEL BANKES ${ }^{* *}$
}

Foreign investors in the energy sector have long sought to secure guarantees from the host state in order to reduce future risk. The international investment law regime has fundamentally altered the legal framework for investors and host states within the energy sector. This article explores the application of international investment law within the energy sector, describes some common categories of disputes that characterize the energy sector, identifies the main disciplines or standards in investment law, and discusses the remedies available to investors.
Les investisseurs étrangers dans le secteur énergétique cherchent depuis longtemps à obtenir des garanties de l'État hôte afin de réduire le risque futur. Le régime de la loi sur l'investissement international a fondamentalement modifié le cadre légal des investisseurs et des États hôtes dans ce secteur. Cet article examine l'application de la loi sur l'investissement international dans ce secteur; il décrit quelques catégories communes de disputes typiques du secteur, identifie les principales disciplines ou normes de la loi sur l'investissement et traite des solutions possibles pour les investisseurs.

\section{TABLE OF CONTENTS}

I. InTRODUCTION . . . . . . . . . . . . . . . . . . . . . . . . 208

II. THE EVOLUtion OF INTERNATIONAL INVESTMENT LAW . . . . . . . . . . 209

III. EXAMPLES OF THE TYPES OF INVESTMENT LAW DISPUTES

THAT ARISE IN THE ENERGY SECTOR . . . . . . . . . . . . . . . 210

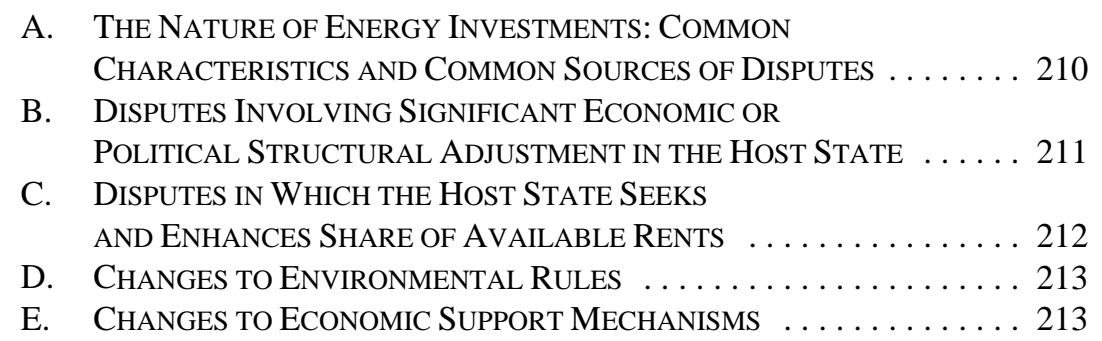

IV. THE DisCipLINES OF INTERNATIONAL INVESTMENT LAW . . . . . . . . . 214

A. NON-ARBITRARY AND NON-DisCRIMINATORY TREATMENT . . . . 216

B. NATiONAL TREATMENT . . . . . . . . . . . . . . . . . . . 218

C. Most-Favoured-Nation TREATMEnT $\ldots \ldots \ldots \ldots \ldots \ldots \ldots 220$

D. Minimum Standard of TREATMENT AND THE

FAir AND EQUitABLE TREATMENT STANDARD . . . . . . . . . 222

E. The Duty Not TO EXPRopriate $\ldots \ldots \ldots \ldots \ldots \ldots \ldots \ldots \ldots$

F. FULL PRotection AND SECURITY $\ldots \ldots \ldots \ldots \ldots \ldots \ldots \ldots . \ldots \ldots$

G. Domestic ReQuirements $\ldots \ldots \ldots \ldots \ldots \ldots \ldots \ldots \ldots \ldots \ldots$

H. Umbrella Clause $\ldots \ldots \ldots \ldots \ldots \ldots \ldots \ldots \ldots \ldots \ldots \ldots$

* $\quad$ Assistant professor of Law and PhD candidate at the University of Calgary.

Professor of Law and Chair of natural resources law at the University of Calgary and adjunct professor at the University of Tromsø, Norway. Both authors acknowledge the research assistance of LLM candidate Omar Chehade. 


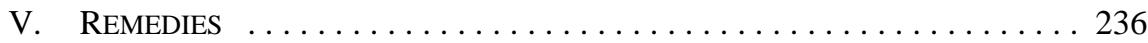

A. RESTITUTION ......................... 237

B. COMPENSATION .......................... 239

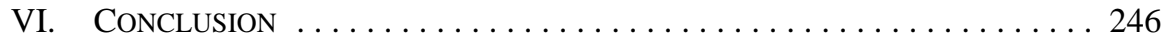

\section{INTRODUCTION}

Investors in the international energy industry have long sought to secure guarantees from the host state in an attempt to reduce the future risk that the host state would unilaterally take measures that would negatively impact their investment interests. ${ }^{1}$ In recent years those guarantees have predominantly come from the international investment law regime, which has fundamentally altered the legal framework for investors and host states in the energy sector. With a far-reaching possibility for international arbitration in the event of disputes, it is an area of law that is continually evolving. Thus, the extent to which foreign investors in the energy sector are protected within the international investment law regime from unilateral state measures remains uncertain. As a result, understanding how arbitrators are giving effect to the protections for investors, while at the same time balancing the interests of host states to regulate in the public interest, is of paramount importance to today's global energy sector.

This article explores the application of international investment law within the energy sector, including upstream oil and gas, electricity generation, and transmission and distribution (natural gas and electricity). International investment law issues were first introduced to the then Canadian Petroleum Law Foundation by John Boscariol in an article entitled "Foreign Investment Protection Treaties: Opportunities in the Petroleum Industry" which he presented to the 41st meeting of the Foundation in June 2005. ${ }^{2}$ Our article aims to build on Boscariol's article both by updating his contribution and also by extending the analysis to cover awards from other parts of the energy sector. The article focuses on the substantive protections afforded investors in international investment law. This article also discusses the remedies available to investors once a breach of those substantive protections is established. That discussion focuses on restitution and compensation as the primary remedies available to investors and highlights some of the factors tribunals consider when awarding those remedies. For the most part, we do not discuss the jurisdictional and interlocutory issues (for example, requests for provisional measures) that often arise in the course of an arbitral proceedings issue. Domestic investment law issues are the subject of another article in this issue.

There are six parts to this article. Following this part, Part II offers some general comments on the evolution of international investment law. Part III describes some categories of investment law disputes that characterize the energy sector. Part IV identifies the main disciplines or standards in investment law drawing upon examples from the energy sector and especially examples that have a connection to Canada (either an international

$1 \quad$ For an examination of the interaction between forms of stability in long-term energy contracts and within the international investment law regime see Peter D Cameron, International Energy Investment Law: The Pursuit of Stability (Oxford: Oxford University Press, 2010).

2 (2006) 44:1 Alta L Rev 115. See also Bernard J Roth, "NAFTA, Alberta Oil Sands Royalties, and Change: Yes We Can?” (2009) 46:2 Alta L Rev 335. 
investment agreement (IIA) to which Canada is a party or a dispute that involves a Canadian entity). Part V discusses remedies available to investors and Part VI provides a conclusion.

\section{THE EVOLUTION OF INTERNATIONAL INVESTMENT LAW}

International investment law has emerged as a sub-discipline of public international law (but one with a distinctive private element) over the last 50 years. It is comprised of a large number of bilateral investment treaties (BITs) (Canada prefers the term foreign investment promotion and protection agreements (FIPAs)) and a much smaller number of regional free trade agreements (FTAs), such as the North American Free Trade Agreement, ${ }^{3}$ that contain investment chapters (chapter 11 in the case of NAFTA). ${ }^{4}$ There is also one relevant subjectspecific investment agreement, the Energy Charter Treaty, although neither Canada nor the United States is a party. ${ }^{5}$ International investment law also draws upon large bodies of general public international law including the law of treaties (especially the interpretation of treaties), much of which has been codified by the Vienna Convention on the Law of Treaties, ${ }^{6}$ and the law of state responsibility, much of which has been codified in a set of Draft Articles adopted by the International Law Commission (ILC) in $2001 .^{7}$

Canada continues to actively negotiate new FTAs and FIPAs, most recently concluding agreements with China, Cameroon, and Zambia. ${ }^{8}$ There are ongoing negotiations with a number of countries and country groups including India and the European Union. ${ }^{9}$

A common element of IIAs is the ability of an investor to invoke the compulsory dispute settlement provisions of the treaty and to initiate arbitral proceedings against a host state with the possibility of claiming damages for breach of one or more of the disciplines of the treaty. A state's consent to arbitration is established by its ratification of the IIA. It is not necessary for a state to establish consent on an individual basis for each dispute. Common forums for such arbitrations include the International Centre for the Settlement of Investment Disputes

3

North American Free Trade Agreement Between the Government of Canada, the United Mexican States and the Government of the United States, 17 December 1992, Can TS 1994 No 2, 32 ILM 289 (entered into force 1 January 1994) [NAFTA].

4 Estimates of the number of BITs in force vary. According to the United Nation's Conference on Trade and Development (UNCTAD) there were 3,164 IIAs including 2,833 BITs and 331 "other IIAs," including, principally, free trade agreements (FTAs) with investment provisions, economic partnership agreements and regional agreements by the end of 2011 (see UNCTAD, World Investment Report 2012: Towards A New Generation of Investment Policies (Geneva: United Nations, 2012) at 84, online: The UNCTAD <http://www.unctad.org/en/PublicationsLibrary/wir2012_embargoed_en.pdf>. Energy Charter Treaty, 17 December 1994, 2080 UNTS 95, 34 ILM 360 (entered into force 16 April 1998) [ECT]. Most of the parties are drawn from western and eastern Europe. Russia signed the Treaty (which resulted in its provisional application) but has since withdrawn its signature. One major producing jurisdiction in Europe that is not a party is Norway. Vienna Convention on the Law of Treaties, 23 May 1969, 1155 UNTS 331, 8 ILM 679 (entered into force 27 January 1980) [VCLT]. The VCLT is widely but not universally ratified (e.g. neither the US nor France is a party); nevertheless it is broadly accepted that many provisions of the VCLT represent customary international law, particularly articles 31-33 dealing with the interpretation of treaties. See generally Richard Gardiner, Treaty Interpretation (Oxford: Oxford University Press, 2008).

Report of the International Law Commission, 53rd Sess, Supp No 10, UN Doc a/56/10 (2001) [Report]. The most important aspects of the general law on state responsibility include the rules relating to attribution (i.e. the rules that stipulate the circumstances in which a state will be responsible for the activities of para-state and private entities operating within its jurisdiction or control), the rules relating to remedies, and the rules relating to "circumstances precluding wrongfulness" (e.g. the defence of necessity).

"Negotiations and Agreements," online: Department of Foreign Affairs, Trade and Development $<$ http://www.international.gc.ca/trade-agreements-accords-commerciaux/agr-acc>. Ibid. 
(ICSID) and the Arbitration Institute of the Stockholm Chamber of Commerce. ${ }^{10}$ The applicable law for such disputes comprises the IIA, the domestic law of the state, and relevant rules of general international law. ${ }^{11}$ In recent years, some states have responded to concerns about the fairness of compulsory arbitration by refusing to participate in the arbitration. ${ }^{12}$ Other states have terminated their consent to dispute settlement in certain arbitration forums. In January 2012, Venezuela denounced ICSID, becoming the third country - after Bolivia and Ecuador — to do so. ${ }^{13}$

\section{EXAMPLES OF THE TYPES OF INVESTMENT LAW DISPUTES THAT ARISE IN THE ENERGY SECTOR}

\section{A. THE NATURE OF ENERGY INVESTMENTS: COMMON CHARACTERISTICS AND COMMON SOURCES OF DISPUTES}

Energy investments tend to be capital intensive and long-term. They are therefore exposed to political and regulatory risk, which is the risk that the host state will change the rules once the investment has been made and before the investor is able to earn a return on, and a return

For more information about the International Centre for the Settlement of Investment Disputes and the Arbitration Institute of the Stockholm Chamber of Commerce visit their websites, online: <http://www. icsid.worldbank.org/ICSID/Index.jsp> and <http://www.sccinstitute.com/skiljeforfarande-2.aspx> .

11 For arbitrations that fall under ICSID see article 42(1) of the Convention on the Settlement of Investment Disputes between States and Nationals of Other States, 18 March 1965, 575 UNTS 159, 4 ILM 532 [ICSID Convention] which provides that the Tribunal shall apply: (1) the rules of law agreed to by the parties and in the absence of such agreement, (2) the law of the State to the dispute (including any conflicts rules) and "such rules of international law as may be applicable." Note that the first part of this clause gives preeminence to any agreement between the parties including, therefore, the provisions of any particular IIA. See e.g. article 26(6) of the ECT, supra note 5 which provides that the tribunal "shall decide the issues in dispute in accordance with this Treaty and applicable rules and principles of international law." Note that some matters such as the construction of a particular agreement (e.g. a production sharing agreement) will fall to be decided under the domestic laws of the host state. See for example, the discussion of applicable law in Burlington Resources Inc v Republic of Ecuador, (2012), Case No ARB/08/5, Decision on Liability (ICSID) at paras 177-79 [Burlington]. The applicable rules of international law include the IIA as the lex specialis and the more general rules of public international law referred to in supra notes 6,7 .

12 See e.g. Mohammad Ammar Al-Bahloul v The Republic of Tajikistan, (2008) Case No V (064/2008) (Arbitration Institute of the Stockholm Chamber of Commerce), Final Award [Al-Bahloul] (Tajikistan chose not to defend itself in a claim initiated by Mr Al-Bahloul as a result of measures taken by the state which allegedly damaged the claimant's investments in Tajikistan's energy sector. The Tajikistan government's failure to participate in the arbitration frustrated the claimant's case as arbitrators were not in a position to secure access to documents in the possession of the government. As a result, Al-Bahloul was not successful in many of his legal claims against the Tajik Republic under the ECT). See also Iurii Bogdanov, Agurdino-Invest Ltd, Agurdino-Chimia JSC v Republic of Moldova, (2005), Case No 93/2004 (Arbitration Institute of the Stockholm Chamber of Commerce), Award [Bogdanov] (Moldova declined to represent itself in a claim brought by a Russian national, Mr Bogdanov. The arbitrator ordered Moldova to bear the costs of the arbitration proceeding (25,000 EUR) for refusing to cooperate).

13 Bolivia, Ecuador, and Venezuela are members of the Bolivarian Alliance for the Americas (ALBA), an organization intended to facilitate economic integration in Latin America. At a Ministerial Conference held in April 2013, members of ALBA and representatives from other Latin American states expressed their support for the establishment of regional dispute resolution mechanisms that could rival ICSID (see Mariano Tobías de Alba Uribe, "Investment Arbitration and Latin America: Irreconcilable Differences?" online: Kluwer Arbitration Blog <http://kluwerarbitrationblog.com/blog/2013/05/21/investmentarbitration-and-latin-america-irreconcilable-differences/>). A "List of Contracting States and Other Signatories of the Convention" is available online: ICSID $<$ https://icsid.worldbank.org/ICSID/FrontServ let?requestType=ICSIDDocRH\&actionVal=ContractingStates\&ReqFrom=Main>. Denunciation of the ICSID Convention alone will be of limited effect if the IIAs to which the denouncing state is a party allow an investor (as they typically do) to choose from amongst a number of different arbitral forums. Furthermore, even if the state goes on to denounce the individual IIAs this will only operate prospectively so as to deprive new investors and investments of the protection afforded by the terms of the IIA. Thus existing investors and their investments will continue to be protected post-denunciation albeit in some cases for a time-limited period. 
of, its investment. ${ }^{14}$ Investors may endeavor to seek security or stability for their investments in a number of ways, including stabilization clauses in investment contracts and the domestic investment laws of host states. ${ }^{15}$ In addition, investors may also seek to structure their investments in a way that takes advantage of the protection offered by IIAs. ${ }^{16}$

While there is tremendous variety in the investment law disputes in the energy sector that have been brought before arbitral bodies, it is helpful to describe four generic types of disputes: (1) disputes involving significant economic or political structural adjustment in the host state; (2) disputes triggered by the efforts of host state governments seeking to claim an enhanced share of resource rents; (3) disputes in which host state governments seek to enhance the environmental or social regulatory regime within which existing investments operate; and (4) disputes in which the host state government seeks to withdraw economic support mechanisms for a policy measure that was introduced to support a particular energy or environmental policy, such as a policy that seeks to reduce greenhouse gas emissions by favouring low carbon or alternative energy sources.

\section{B. DisPUTES INVOLVING SigNifiCANT ECONOMIC or Political Structural Adjustment in the Host State}

A significant number of international investment disputes involve host states responding to severe economic crises. In some cases, the crisis may be isolated to one jurisdiction or a small group of jurisdictions, and, in other cases, the crisis may be more global. ${ }^{17}$ One of the characteristics of this category of disputes is that the host state typically tries to justify its actions on the basis that the treaty in question (and obviously this is contingent on the text of the treaty) authorizes special measures in the event of exceptional circumstances and that therefore such measures do not constitute a breach of the treaty. Alternatively, or where there is no internal special measures clause, the state may argue that such measures are justified under the customary rules of international law on state responsibility, specifically the rules dealing with necessity. ${ }^{18}$

Anotole Boute, "The Potential Contribution of International Investment Protection Law to Combat Climate Change” (2009) 27:3 Journal of Energy \& Natural Resources Law 333 at 337.

15 Peter D Cameron, "Stability of Contract in the International Energy Industry" (2009) 27:3 Journal of Energy \& Natural Resources Law 305 canvasses different legal techniques that may be adopted to achieve a degree of stability or security for an international energy investment.

16 An investor's nationality usually determines which treaties afford protections for its investment. Determining corporate nationality, however, is more complicated than determining the nationality of an individual, which is primarily determined by the law of the country whose nationality is claimed. The most commonly used criteria for assessing corporate nationality are the place of incorporation or the main seat of the business. For example, the ECT"s definition of "investor" includes "a company or other organization organized in accordance with the law applicable in that Contracting Party" (ECT, supra note 5 at article 1(7)(a)(ii)). In cases in which the relevant treaty stresses incorporation as the criterion for determining corporate nationality, arbitral tribunals will not pierce the corporate veil and consider the nationality of the claimant's owners (see e.g. Saluka Investments $B V \vee$ The Czech Republic, UNCITRAL, Partial Award (17 March 2006) [Saluka]). As a result, in many cases investors will use as an investment vehicle an entity incorporated in a state that has a favourable IIA with the host state.

17 In 2012 cases were initiated against Belgium and Greece over measures taken during the recent global financial crisis and ongoing economic recession in the EU (see e.g. Ping An Life Insurance Company of China, Limited and Ping An Insurance (Group) Company of China, Limited $v$ Kingdom of Belgium (2012), Case No ARB/12/29 (ICSID); Luke Eric Peterson, "Investment Treaty Arbitration against Greece Looms after Foreign Bank Gives Notice of Dispute Due to ‘Discriminatory' Bail-out” (27 March 2013), online: IA Reporter <http://www.iareporter.com/articles/20130327>.

18 See e.g. CMS Gas Transmission Company v Argentine Republic (2007), Case No ARB/01/8 (ICSID), Annulment Proceeding [CMS Annulment Proceeding]. 
A prominent example of this type of dispute arose out of the economic crisis that faced Argentina between 2001 and 2002 after it had liberalized many of its markets, including its energy market, to attract foreign investment in the 1990s. Argentina responded to that crisis with a number of measures including the forced conversion of contracts and tariffs into pesos (rather than American dollars, "pesification”), withholding taxes, changes in pricing mechanisms, and refusals to pay for generation. ${ }^{19}$ These measures had a significant impact on investors, including those in Argentina's energy sector, both in the upstream sectors of the industry and the downstream utility business.

To date, Argentina is the most frequent respondent in investor-state disputes with 49 of the 52 cases against Argentina being brought to ICSID. ${ }^{20}$ Thus far, the cases that have been adjudicated have collectively resulted in Argentina being liable to investors for hundreds of millions of dollars. ${ }^{21}$ Even more noteworthy than those statistics is the difficulty arbitral tribunals have had interpreting Argentina's necessity defence in many of those cases. While the majority of arbitral panels have rejected Argentina's invocation of necessity, they have taken different analytical approaches to Argentina's arguments, resulting in incoherent jurisprudence and uncertainty regarding a host state's ability to respond in situations of economic crisis without liability under international investment law. ${ }^{22}$

\section{Disputes IN WHICH THE Host STATE SEEKS AN ENHANCED SHARE OF AVAILABLE RENTS}

A frequent source of disputes between host state governments and energy investors are the efforts of governments to claim an enhanced share of resource rents (that is, increase the government take) when world energy prices increase suddenly or unexpectedly. For example, a number of governments in Central and South America, including Ecuador, Bolivia, and Venezuela, have all taken measures to enhance their share of rents. ${ }^{23}$ The measures include new taxes, pressure to re-negotiate existing agreements, revocation of existing agreements, or changing the tax treatment of goods supplied to the energy sector. Royalty reviews and similar measures are not confined, however, to OPEC members. Other jurisdictions,

Total SA v Argentine Republic (2010), Case No ARB/04/1 (ICSID), Decision on Liability [Total SA]. A list of both pending and concluded cases filed with ICSID can be found on its website, supra note 13. See also UNCTAD, "Recent Developments in Investor-State Dispute Settlement," online: UNCTAD <http://unctad.org/en/PublicationsLibrary/webdiaepcb2013d3_en.pdf>.

José E Alvarez \& Kathryn Khamsi, "The Argentine Crisis and Foreign Investors: A Glimpse into the Heart of the Investment Regime” in Karl P Sauvant, ed, Yearbook on International Investment Law \& Policy 2008-2009 (New York: Oxford University Press, 2009) 379 at 380. See also Susan D Franck, “Empirically Evaluating Claims About Investment Treaty Arbitration” (2007) 86:1 NCL Rev 1 at 58, 60 (where the author finds that out of 52 publicly available investor-state dispute cases that decided damages, one of four tribunals awarded over \$10 million in a claim against Argentina).

For the different approaches to the interpretation of the necessity defence see e.g. $C M S$, Annulment Proceeding, supra note 18; Enron Corporation and Ponderosa Asses, LP v Argentine Republic (2010), Case No ARB/01/3 (ICSID), Decision on the Application for Annulment of the Argentine Republic [Enron]; LG\&E Energy Corp, LG\&E Capital Corp, LG\&E International Inc v Argentine Republic (2006), Case No ARB/ 02/01 (ICSID), Decision on Liability [LG\&E].

A recent award dealing with Ecuador's “windfall” tax on incremental petroleum rents is Burlington Resources Inc v Republic of Ecuador (2012), Case No ARB/08/5 (ICSID), Decision on Liability [Burlington]. See also Sergei Paushok, CJSC Golden East Company and CJSC Vostokneftegaz Company $v$ The Government of Mongolia, UNCITRAL, Award on Jurisdiction and Liability (28 April 2011); City Oriente Limited $v$ The Republic of Ecuador and Empresa Estatal Petróleos Del Ecuador (2007), Case No ARB/06/21 (ICSID), Decision on Revocation of Provisional Measures and Other Procedural Matters. 
including Alberta and the United Kingdom, have also reviewed rent collection mechanisms in light of changing circumstances. ${ }^{24}$

\section{CHANGES TO ENVIRONMENTAL RULES}

Another source of dispute can be changes by the host state to the environmental regime within which the energy industry operates. Such changes may increase the cost of doing business and in some cases may make it impossible to continue with a particular type of operation. One example of such changes involves Germany's decision to phase out nuclear energy. ${ }^{25}$ Another example relates to legislative and regulatory changes made by the State of California in 2003 requiring investors in the metallic mining industry to completely backfill their open-pit mines, grade excavations for their projects to the original contours of the land, and provide financial assurances about their ability to meet those backfill and grading requirements. ${ }^{26}$

\section{E. Changes in Economic SuPPORT MECHANISMS}

Efforts to decarbonize the economy have led governments around the world to develop incentive programs to encourage the development of alternative energy sources and new and innovative technologies such as carbon capture and storage. Incentive programs may take a number of forms including direct subsidies and feed in tariff programs. ${ }^{27}$ Disputes may arise where governments seek to withdraw or change these programs; there may also be disputes regarding eligibility for these programs, especially where host governments seek to include domestic performance requirements in order to foster the development of the "green economy." ${ }^{28}$ Governments offer a number of reasons for changing or withdrawing these types

$24 \quad$ See Roth, supra note 2.

25 Vattenfall $A B$ and others $v$ Germany (2013), Case No ARB/12/12 (ICSID), Tribunal Reconstituted.

26 Glamis Gold Ltd v United States of America, UNCITRAL, Award (8 June 2009) [Glamis]. In November 2012 an oil and gas exploration, development, and production company (Lone Pine Inc) indicated its intent to commence NAFTA chapter 11 proceedings against Canada after a law passed within Quebec revoked its right to mine for oil and gas beneath the St Lawrence River. As a result, Lone Pine Inc alleges that its investments in Quebec's Utica Shale Gas Basin have been expropriated and treated unfairly and inequitably ("Notice of Intent to Submit a Claim to Arbitration Under Chapter 11 of the North American Free Trade Agreement" (8 November 2012), online: <http://www.international.gc.ca/ trade-agreements-accords-commerciaux/assets/pdfs/disp-diff/lone-01.pdf $>$ ).

27 Ontario established a FIT program a few years ago under the Green Energy and Green Economy Act, SO 2009, c 12. The program is administered by the Ontario Power Authority and permits (1) large-scale renewable energy developers (projects over 10 kilowatts) ("FIT projects") and (2) homeowners or smallscale businesses (10 kilowatts or less) ("micro-FIT projects”), with qualifying renewable energy sources (bioenergy, solar photovoltaic cells, wind, and water) to enter into sales contracts with the OPA for their electric energy production, provided such energy producers use a prescribed percentage of materials and labour from Ontario suppliers for their projects. For more information about Ontario's FIT and microFIT programs see Ontario Power Authority, "General Information about the FIT and microFIT Programs,” online: Ontario Power Authority <http://fit.powerauthority.on.ca/program-resources/faqs/ general-information-about-fit-and-microfit-programs $>$.

28 Nigel Bankes, "Decarbonising the Eonomy and International Investment Law" (2012) 30:4 Journal of Energy \& Natural Resources Law 497. Ontario’s FIT and micro-FIT programs have recently been successfully challenged by the European Union and Japan at the WTO for discriminating against foreign produced renewable energy generation components (see Panel Reports, Canada - Certain Measures Affecting the Renewable Energy Generation Sector and Canada - Measures Relating to the Feed-In Tariff Program WT/DS412/R, WT/DS426/R, circulated 19 December 2012; Appellate Body Reports, Canada - Certain Measures Affecting the Renewable Energy Generation Sector \& Canada Measures Relating to the Feed-In Tariff Program, WT/DS412/AB/R, WT/DS426/AB/R, circulated 6 May 2013). Investors have also alleged discrimination in the context of Ontario's subsidy scheme (see Mesa Power Group, LLC v Government of Canada, UNCITRAL, Notice of Arbitration (4 October 2011)). 
of programs. In some cases, the programs prove more popular (and therefore more expensive) than anticipated. In other cases, such programs are perceived as being too generous either because the new technology has come to be seen as business as usual (and therefore not requiring an incentive) or because the production costs for the new technology have decreased significantly therefore reducing the need for, or the amount of, any incentive payment. $^{29}$

\section{THE DISCIPLINES OF INTERNATIONAL INVESTMENT LAW}

The disciplines of international investment law refers to the standards that IIAs impose on the host state with respect to the manner in which it, and those entities for which it must assume responsibility, ${ }^{30}$ deals with foreign investors. It is important to emphasize that in each and every case the starting point will be the text of the relevant treaty (as supplemented where appropriate by the application of the most-favoured-nation rules), but there is a core content of IIAs that is common to most agreements. The core content includes the following: the national treatment (NT) standard, the most-favoured-nation (MFN) standard, the fair and equitable treatment (FET) standard, the duty not to expropriate except for a public purpose and upon payment of compensation, and the duty of full protection and security. Broad prohibitions against arbitrariness and discrimination are also part of the protections afforded to investors in some IIAs.

IIAs will also often contain exceptions and permit state parties to make reservations to some of the above substantive protections. ${ }^{31}$ For example, article 8 of the Canada-China FIPA exempts all existing non-conforming measures maintained within the territory of the contracting parties from the NT and MFN standards. The renewal and timely continuation of those non-conforming measures is also permitted. In addition, those non-conforming measures may be amended, provided that such amendments do not further decrease the conformity of the measure with the NT and MFN standards. ${ }^{32}$ This exception in the CanadaChina FIPA is not industry specific. As a result, it broadly carves out from those substantive

See for example the arbitration initiated against the Government of Canada under NAFTA Chapter 11 as a result of changes to the development offshore wind projects in Ontario (Windstream Energy LLC $v$ Government of Canada, UNCITRAL, Notice of Arbitration (28 January 2013)).

30 See Report, supra note 7, arts 4-11 (which outline the circumstances in which a state will be responsible in international law for the activities of its sub-national governments as well as para-state and private entities operating within its jurisdiction or control).

31 NAFTA authorizes each party to take a reservation to the NT standard, the MFN standard, and domestic performance requirements (see NAFTA, supra note 3, art 1108). Similarly, the ECT allows a party to take a reservation to the umbrella clause commitment (ECT, supra note 5, arts 10(1), 26(3)(c)). For a thorough examination of the exemptions and reservations available to investors under NAFTA, including those particular to the oil and gas industry, see Boscariol, supra note 2 at 124-26.

32 Agreement Between the Government of Canada and the Government of the People's Republic of China for the Promotion and Reciprocal Protection of Investments, negotiations concluded 9 September 2012, online: Foreign Affairs, Trade and Development Canada <http://www.international.gc.ca/trade-agree ments-accords-commerciaux/agr-acc/fipa-apie/china-text-chine.aspx?lang=eng $>$. Article 8(2) states:

2. Articles 5, 6 and 7 do not apply to:

(a)

(i) any existing non-conforming measures maintained within the territory of a Contracting Party; and

(b) the continuation or prompt renewal of any non-conforming measure referred to in subparagraph (a); or

(c) an amendment to any non-conforming measure referred to in sub-paragraph (a), to the extent that the amendment does not decrease the conformity of the measure, as it existed immediately before the amendment, with Articles 5, 6 and 7. 
protections “any law, regulation, rule, procedure, decision, requirement, administrative action, or practice” ${ }^{33}$ existing on the date the FIPA enters into force, ${ }^{34}$ applicable to any Canadian industry, including the energy sector. ${ }^{35}$ The precise contours of a similarly worded exception under NAFTA are discussed in more detail below (see Part IV.G).

The discussion below highlights some of the key issues affecting the content of the core international investment law disciplines. For example, some standards of protection clearly overlap with other treaty protections making it difficult, in some circumstances, to articulate the scope of certain disciplines. This is particularly true of the protections against arbitrary and discriminatory treatment. Tribunals have tended to decide claims under those protections on the basis of the FET or NT standards, respectively. In addition, there are disagreements about the scope of many of these standards of protection. One of the more prominent disagreements involves the MFN clause and in particular the question of whether or not the clause applies to procedural rights such as the dispute settlement provisions of an investment agreement so as to allow an investor to take advantage of a more favourable dispute settlement agreement in another IIA. ${ }^{36}$ Further, the interpretation of the FET and full protection and security standards has also proven to be contentious. Tribunals struggle to delineate the parameters of those disciplines in a manner that is coherent and creates more certainty for investors and host states.

Another issue that pervades arbitral jurisprudence regarding the core disciplines in IIAs is the balance that is struck between the right of the host state to regulate in the public interest and the rights of the investor. One of the ways that arbitral tribunals have attempted to address this issue (rightly or wrongly) is to import considerations of reasonableness and proportionality into their analyses of the FET standard and the duty not to expropriate. Such parameters have yet to influence cases involving the NT obligation, but one would expect such considerations to become more prominent in discussions on the scope of the NT standard as investor-state jurisprudence continues to develop.

Recent jurisprudence considering disciplines that are not part of the core elements of IIAs (for example, domestic content requirements) also raises concerns about limits imposed on the regulatory powers of states within the international investment law regime. ${ }^{37}$ More specifically, a recent split decision interpreting Canada's reservation to the prohibition on domestic performance requirements under NAFTA article 1106 raises questions about a host state's ability to adopt new regulations, guidelines, and policies under its reserved powers.

\footnotetext{
Ibid, art 1(6).

Ibid, art 1(7).

Similarly worded reservations exist in many of Canada's FIPAs (see e.g. supra note 8).

For a review of the jurisprudence see Elizabeth Whitsitt, “Application of Most-Favoured-Nation Clauses to the Dispute Settlement Provisions of Bilateral Investment Treaties: an Assessment of the Jurisprudence” (2009) 27:4 Journal of Energy \& Natural Resources Law 527; Elizabeth Whitsitt, "Application of MFN Clauses to the Dispute Settlement Provisions of BITs: an Updated Assessment of the Jurisprudence since Wintershall” (2011) 2:1 Journal of Arbitration and Mediation 21.

37 See Nigel Bankes, "From Regulatory Chill to Regulatory Concussion: NAFTA's Prohibition on Domestic Performance Requirements and an Absurdly Narrow Interpretation of Country Specific Reservations," online: University of Calgary Faculty of Law Ablawg <http://www.ablawg.ca/2013/ 05/06/from-regulatory-chill-to-regulatory-concussion-naftas-prohibition-on-domestic-performancerequirements-and-an-absurdly-narrow-interpretation-of-country-specific-reservations/> [Bankes, "From Regulatory Chill”].
} 
In addition to interpretive concerns about the protections offered investors within the international investment regime, uncertainties remain with respect to whether an investor is protected under IIAs for contractual obligations a host state has pursuant to agreements (that is, concession agreements) it has entered into with the investor, or more typically the investor's local subsidiary. Some IIAs provide the so-called umbrella clause protection pursuant to which the host state agrees to observe any obligations it owes to an investor of the other state party. The interpretation and application of this clause (where available) has proven to be particularly contentious. While some contend that it serves to elevate any contractual obligation breached by a state to the level of a treaty breach, others take a more limited approach contending that it only applies to the state when acting in its sovereign capacity or use the principles of attribution and privity to limit its application. ${ }^{38}$

With those introductory comments on the disciplines of international investment law in mind, the following discussion provides a more in-depth discussion of each discipline in the context of the energy sector.

\section{A. NON-ARBITRARY AND NON-DISCRIMINATORY TREATMENT}

Prohibitions against arbitrary treatment have a long-standing presence in IIAs and are often placed in the same treaty provision as prohibitions against discriminatory treatment. ${ }^{39}$ Given their co-existence within the same treaty clause, some might mistakenly think that the two standards are the same. However, establishing a violation of this provision in an investment treaty does not require a foreign investor to prove that a measure is both arbitrary and discriminatory; a violation of either standard will be sufficient. ${ }^{40}$

\section{ARBITRARINESS}

Arbitral tribunals have confirmed that measures will violate the prohibition against arbitrariness if: (1) they damage a foreign investor for no legitimate purpose ${ }^{41}$ (2) they are not based on legal standards but on discretion; ${ }^{42}$ (3) they are taken without regard to due

See note 165 below.

See e.g. article II(2)(b) of the US-Argentina BIT which provides that "[n]either party shall in any way impair by arbitrary or discriminatory measures the management, operation, maintenance, use, enjoyment, acquisition, expansion or disposal of investments." "Treaty between United States of America and The Argentine Republic Concerning the Reciprocal Encouragement and Protection of Investment” (signed 14 November 1991), online: UNCTAD < http://www.unctad.org/sections/dite/iia/docs/bits/argentina_us. pdf $>$. For a variation in wording see article 10(1) of the $E C T$, supra note 5 which prohibits state parties from taking "unreasonable or discriminatory measures."

40 This is due to the language of typical treaty clauses which separate the two standards using the disjunctive conjunction or which suggests that each standard has its own meaning. Arbitral jurisprudence considering such clauses confirms this interpretation (see e.g. Azurix Corp v Argentine Republic (2005), Case No ARB/01/12 (ICSID), Award at para 391 [Azurix]).

41 See e.g. Enron, Corporation and Ponderosa Assets, LP v Argentine Republic (2007), Case No ARB/01/3 (ICSID), Award at para 281 [Enron, Award]; Sempra Energy International v Argentine Republic (2007), Case No ARB/02/16 (ICSID), Award at para 318 [Sempra] (where the tribunals in both disputes dismissed arguments related to violations of the arbitrariness standard because it determined that the Argentinian government believed it was responding in the best way possible to its financial crisis). authorities prohibiting Azurix from collecting tariffs in relation to its water and sewage operations were arbitrary because they were not based on the law or the concession agreement). 
process or proper procedure ${ }^{43}$ or (4) they are ostensibly implemented for public purposes but are in fact intended to harm the investor. ${ }^{44}$

Despite their ubiquitous presence in IIAs and the popularity of such arguments in investorstate disputes, few cases are determined on the basis of this standard. In fact many cases involving the prohibition against arbitrary treatment also engage and are decided on the basis of the FET discipline. ${ }^{45}$ One such recently decided case arose out of Argentina's economic crisis in 2001 and involved a US company that owned indirect and non-controlling shareholdings in a number of Argentinian companies in the electricity and hydrocarbons sector.

In El Paso Energy International Company v. The Argentine Republic, ${ }^{46}$ El Paso argued that a number of measures (that is, export withholdings on crude oil, foreign exchange controls, and a pesification policy) taken by Argentina during its financial crisis rendered its investments worthless and breached undertakings assumed by Argentina when its investments were originally made. El Paso asserted numerous violations of the US-Argentina BIT, including the prohibition against arbitrariness and the FET standard. ${ }^{47}$ With respect to arbitrariness, El Paso asserted that Argentina's response to its economic crisis was politically motivated. The Tribunal disagreed. Recognizing that there are a variety of responses states can implement in times of crises, the Tribunal observed that Argentina's response to its economic situation beginning in 2001 was reasonable and emanated from the police powers regularly exercised by governments. ${ }^{48}$ The Tribunal did, however, find Argentina in violation of the FET standard under the US-Argentina BIT and common to most IIAs. ${ }^{49}$ That portion of the Tribunal's decision is referenced below.

\section{DISCRIMINATION}

The prohibition against discrimination coexistent in clauses prohibiting arbitrariness is closely tied to the NT and MFN standards discussed below. While scholars note that claims of discrimination need not be limited to distinctions on the basis of nationality, most of the arbitral jurisprudence examining the prohibition against discriminatory treatment addresses distinctions made on that basis. ${ }^{50}$

ex Occidental Exploration and Production Company v Republic of Ecuador (2004), Case No UN 3467 (London Court of International Arbitration), Final Award at para 163 [OEPC I] (where the Tribunal determined that the Ecuadorian tax authority's inconsistent reimbursements of value-added tax to businesses was arbitrary because it acted with a lack of clarity and confusion). See e.g. CME v Czech Republic, UNCITRAL, Partial Award (13 September 2001) at para 612 (where the Tribunal found a violation of the prohibition against arbitrariness in the Netherlands-Czech BIT because the regulatory authority governing media in the Czech Republic created a legal situation that enabled the termination of the broadcasting services contract on which CME's investment relied). See e.g. PSEG Global Inc, North American Coal Corporation, and Konya Ilgin Electrick Uretim ve Ticaret Limited Sirketi $v$ Republic of Turkey (2007), Case No ARB/02/5 (ICSID), Award [PSEG Global].

46 El Paso Energy International Company v Argentine Republic (2011), Case No ARB/03/15 (ICSID), Award [El Paso].

Ibid at paras 89-122, 215-24.

Ibid at paras 320-22.

See also Sempra, supra note 41 at paras 290-304, 318-19 (where the Tribunal held that measures taken by Argentina during its economic crisis violated the FET standard but were not arbitrary because the Argentine government took measures it believed to be the best response to the country's unfolding circumstances).

50 Rudolf Dolzer \& Christoph Schreuer, Principles of International Investment Law, 1st ed (Oxford: Oxford University Press, 2008) at 176-78. 
A recent decision in a dispute between Total S.A. and Argentina exemplifies the difficulty that a foreign investor faces in establishing a violation of the discrimination clause in a IIA. In Total S.A. ${ }^{51}$ the French multinational claimant argued that its investment (that is, shareholdings) in Argentina's electricity sector had suffered discrimination. In particular, Total asserted that certain measures taken by Argentina during its economic crisis severely restricted the price of electricity in order to subsidize other sectors of the economy, including the export industry, to the detriment of investors in Argentina's energy sector. ${ }^{52}$ The Tribunal rejected these arguments, finding that "such a policy would not per se represent a breach of the non-discrimination standard. This standard requires, as a rule, a comparison between the treatment of different investments, usually within a given sector, of different national origin or ownership."53

Another example of the connection between the prohibition against discrimination and distinctions based on nationality is Nykomb Synergetics Tech. Holding AB v. Republic of Latvia, ${ }^{54}$ a case decided under article $10(1)$ of the ECT, which prohibits states from impairing the use, enjoyment, or disposal of investments by "unreasonable or discriminatory measures.” In 1999, the claimant, a Swedish company, acquired a Latvian subsidiary (Windau). Prior to this acquisition Windau had contracted with the state-owned Latvian electricity distribution company (Latvenergo) to construct an energy efficient co-generation plant. In return, Latvenergo agreed to purchase electricity from Windau at a higher price than usual. After the construction of the plant was finished in 1999, Latvenergo refused to pay the agreed upon price. ${ }^{55}$

As a result, the claimant initiated arbitral proceedings against Latvia alleging that Latvenergo's refusal to pay the higher price was discriminatory in light of the fact that Latvenergo had purchased electricity at that rate from two other Latvian generation facilities. ${ }^{56}$ The Tribunal found that this constituted a discriminatory measure under article $10(1)$ of the $E C T{ }^{57}$ Given the nature of the arguments raised, one can also imagine Nykomb as a NT case, along with the discussion in the next section of the NT standard of protection, that does indeed argue that the Tribunal in Nykomb applied the framework of analysis used by other arbitral tribunals when determining violations of the NT standard.

\section{B. NATiOnAl TREATMENT}

NT standards appear in most IIAs. ${ }^{58}$ Broadly stated, such clauses ensure that a host state accords foreign investors and their investments treatment that is no less favourable than the treatment it provides to its own investors in comparable circumstances, unless such

Total SA, supra note 19.

Ibid at paras 213-15, 344.

Ibid at para 344.

Nykomb Synergetics Tech Holding AB v Republic of Latvia (2003), Case No 118/2001 (Arbitration Institute of the Stockholm Chamber of Commerce), Award [Nykomb].

Ibid at para 1.1 .

Ibid.

Ibid at para 4.3.2(a).

For a discussion of varying NT clauses existing in IIAs, see Andrew Newcombe \& Lluis Paradell, Law and Practice of Investment Treaties: Standards of Treatment (Bedfordshire: Kluwer Law International, 2009) at $156-59$. 
distinctions are justifiable for public policy reasons. ${ }^{59}$ The rationale for the inclusion of such clauses in IIAs is to protect foreign investors from differential treatment that favours domestic investors. The NT standard thus precludes host states from discriminating against foreign investors on the basis of nationality but offers no refuge to foreign investors if a host state's domestic investors are also treated badly.

The framework for applying the NT standard to a particular case requires an arbitral tribunal to manoeuver through three questions. The first question to be addressed is whether the foreign investor and the domestic investor are in comparable circumstances. ${ }^{60}$ Second, an arbitral tribunal must determine whether the treatment accorded to the foreign investor is de jure or de facto less favourable than the treatment accorded to domestic investors. ${ }^{61}$ The third and final question to be addressed is whether a host state's differential treatment is justifiable on public policy grounds. As discussed below, arbitral tribunals examining the FET standard and the duty not to expropriate have imported considerations of reasonableness and proportionality in order to balance a host state's right to regulate with the rights of foreign investors under IIAs. However, arbitral jurisprudence has yet to provide clear guidelines articulating the boundaries of the third stage in the analytical framework applying the NT standard to host states. ${ }^{62}$

The Nykomb decision applied at least the first two steps of this analytical framework. The tribunal noted that there were Latvian investors operating in comparable circumstances (that is, co-generation electricity plants) which continued to receive a higher price for their electricity, while such payments were withheld from the Swedish claimant. ${ }^{63}$ Latvia attempted to avoid the allegation by arguing that the co-generation facilities were not in comparable circumstances. However, the Tribunal rejected those arguments, finding that Latvia had not tendered any evidence justifying the different (that is, higher prices) paid to certain domestic co-generation facilities. ${ }^{64}$ As a result, the Tribunal ordered Latvia to compensate the claimant for its losses up to the date of the award and ordered that Latvia pay the higher price for electricity delivered for the remainder of the contract. ${ }^{65}$

Dolzer \& Schreuer, supra note 50 at 178-83.

The basis of comparison at this first stage in the analysis remains controversial within the jurisprudence. Some arbitral tribunals require foreign and domestic investors to be in the same line of business (see e.g. Marvin Feldman v Mexico (2002), Case No ARB(AF)/99/1 (ICSID), Final Award [Feldman]) while other arbitral tribunals have determined that such comparisons need only be made within the same industry sector (see e.g. OEPC I, supra note 43).

61 See e.g. International Thunderbird Corporation v United Mexican States, UNCITRAL, Award (26 January 2006) at para 183 (where the Tribunal determined that a violation of the NT obligation in NAFTA did not require the claimant to show an intent to discriminate on the basis of nationality and instead found that a violation of NT need only be substantiated by the factual existence of less favourable treatment). For similar findings on the role of intent in NT, see also ADF Group Inc $v$ United States (2003), Case No ARB(AF)/00/1 (ICSID), Award at para 157; SD Myers, Inc v Government of Canada, UNCITRAL, First Partial Award (13 November 2000) at para 254 [SD Myers]; Siemens AG $v$ Argentine Republic (2007), Case No ARB/02/8 (ICSID), Award at para 321 [Siemens, Award].

Dolzer \& Schruer, supra note 50 at 181-83.

Nykomb, supra note 54 at para 4.3.2.

Ibid.

See ibid at para 5.2. 


\section{Most-Favoured-NATION TREATMENT}

In addition to protecting foreign investors from measures that protect a host state's domestic investors, IIAs contain MFN clauses, which provide that a host state afford investors or investments from one foreign country treatment "no less favourable" than that provided to investors or investments from any other foreign country ${ }^{66}$ Despite their pervasive presence in IIAs, the proper scope and application of MFN clauses is a divisive issue within the international investment law regime. More specifically, questions have arisen regarding the extent to which an investor can use a MFN clause to access what are perceived to be more favourable dispute-settlement provisions in other IIAs between the host state and a third state.

There are numerous arbitral decisions considering those questions, and they have resulted in inconsistent findings with respect to the proper interpretation and application of MFN clauses in IIAs. ${ }^{67}$ Thus far, investors have sought to use MFN clauses to gain access to an expedited arbitration process ${ }^{68}$ or as a way of vesting arbitral tribunals with jurisdiction over classes of claims not contemplated or expressly excluded under a BIT. ${ }^{69}$ For a while it appeared that tribunals were comfortable extending MFN protection to investors who sought expedited processes but not to those seeking to vest a tribunal with jurisdiction. Such explanations no longer help to explain the jurisprudence on MFN given more recent decisions. Two recently decided cases in the oil and gas sector highlight the nature of the controversy surrounding MFN protection in investor-state disputes.

In RosInvestCo, ${ }^{70}$ the claimant alleged losses to its shareholdings in the Yukos Corporation as a result of "arbitrary” tax assessments imposed by the Russian Government

UNCTAD, Most-Favoured Nation Treatment, (New York: United Nations, 2010) at 12-33. See also OECD, Most-Favoured-Nation Treatment in International Investment Law, Working Paper No 2004/2 (2004) at 2.

67 See e.g. Emilio Agustín Maffezini v Kingdom of Spain (2007), Case No ARB/97/7 (ICSID), Decision on Jurisdiction [Maffezini]; Siemens AG v Argentine Republic (2004), Case No ARB/02/8 (ICSID), Decision on Jurisdiction [Siemens, Jurisdictional Decision]; Suez, Sociedad General de Aguas de Barcelona SA and InterAguas Servicios Integrales del Agua SA v Argentine Republic (2006), Case No ARB/03/17 (ICSID), Decision on Jurisdiction [Suez Sociedad]; Gas Natural SDG, SA v Argentine Repubic (2005), Case No ARB/03/10 (ICSID), Decision of the Tribunal on Preliminary Questions of Jurisdiction [Gas Natural]; National Grid PLC v Argentine Republic, UNCITRAL, Decision on Jurisdiction (20 June 2006) [National Grid]; Salini Costruttori SpA; and Italstrade SpA v Hashemite Kingdom of Jordan (2004), Case No ARB/02/13 (ICSID), Decision on Jurisdiction [Salini]; Plama Consortium Limited $v$ Republic of Bulgaria (2008), Case No ARB/03/24 (ICSID), Decision on Jurisdiction [Plama]; Telenor Mobile Communications AS v Republic of Hungary (2006), Case No ARB/04/15 (ICSID), Award [Telenor]; Vladimir Berschader and Moïse Berschader $v$ Russian Federation (2006), Case No 080/2004 (Arbitration Institute of the Stockholm Chamber of Commerce), Award [Berschader]; RosInvestCo UK Ltd v Russian Federation (2007), Case No V 079/2005 (Arbitration Institute of the Stockholm Chamber of Commerce), Award on Jurisdiction [RosInvest]; Wintershall Aktiengesellschaft v Argentine Republic (2008), Case No ARB/04/14 (ICSID), Award [Wintershall]; Renta 4 SVSA v Russian Federation (2009), Case No 24/2007 (Arbitration Institute of the Stockholm Chamber of Commerce), Award Preliminary Objections [Renta 4]; Tza Yap Shum v Republic of Peru (2009), Case No ARB/07/6 (ICSID), Decision on Jurisdiction and Competence [Shum]; Austrian Airlines v Slovak Republic, UNCITRAL Case No redacted, Final Award (9 October 2009) [Austrian Airlines]; Impregilo SpA v Argentine Republic (2011), Case No ARB/07/17 (ICSID), Award [Impregilo]. See e.g. Maffezini, ibid; Siemens, Jurisdictional Decision, ibid; Suez, ibid; Gas Natural, ibid; National Grid, ibid; Wintershall, ibid; Impregilo, ibid.

$69 \quad$ Salini, supra note 67; Plama, supra note 67; Telenor, supra note 67; Berschader, supra note 67; RosInvest, supra note 67; Renta 4, supra note 67; Shum, supra note 67; Austrian Airlines, supra note 67.

RosInvest, ibid. 
in violation of the UK-Soviet BIT. ${ }^{71}$ The UK-Soviet BIT only permitted investor-state arbitration in case of disputes over the amount of compensation, or disputes concerning any other matter consequential upon an act of expropriation. ${ }^{72}$ Attempting to overcome those strict requirements, the claimant invoked the MFN clause in the UK-Soviet BIT and argued that such protection should permit it to access the arbitration clause contained in a BIT between Denmark and Russia. ${ }^{73}$ In response, Russia argued that the MFN clause could not be used to replace the deliberately chosen narrow grant of jurisdiction with a broader grant of jurisdiction such as that from the Denmark-Russia BIT. ${ }^{74}$

The Tribunal rejected Russia's position and determined that the very character and intention of an MFN clause is to ensure that "protection not accepted in one treaty is widened by transferring the protection accorded in another treaty."75 This effect was generally accepted in relation to substantive treaty protections (that is, FET or full protection and security) and the Tribunal could identify no reason not to apply this approach in the procedural context. ${ }^{76}$

In Wintershall, ${ }^{77}$ the claimant argued that Argentina took a number of measures that negatively impacted its oil and gas operation and violated the Argentina-Germany BIT. ${ }^{78}$ Notwithstanding a provision in the Argentina-Germany BIT that requires disputes to first be brought to the Argentine courts, the claimant in this case submitted its claims directly to arbitration. ${ }^{79}$ Invoking the MFN clause, the claimant argued that it was entitled to utilize more favourable dispute settlement procedures in the Argentina-US BIT, which did not require investors to submit disputes to local courts prior to initiating arbitration. ${ }^{80}$

The Tribunal in this case found that it did not have jurisdiction to hear Wintershall's case. ${ }^{81}$ In so finding, the Tribunal decided that Wintershall could not avoid prior compliance with the procedural requirements in the Argentina-Germany BIT by virtue of its MFN clause. $^{82}$ The Tribunal in Wintershall centred its discussion on the principle of consent and noted that:

[T]he eighteen-month requirement of a proceeding before local courts (stipulated in Article 10(2)) is an essential preliminary step to the institution of ICSID Arbitration, under the Argentina-Germany BIT; it constitutes an integral part of the "standing offer" (“consent”) of [Argentina], which must be accepted on the same terms by every individual investor who seeks recourse (ultimately) to ICSID arbitration for resolving its dispute with the Host State under the concerned BIT. ${ }^{83}$

Ibid at para 3.

See ibid at para 23.

Ibid at paras 89, 99.

Ibid at paras 87-88.

Ibid at para 131 .

Ibid at para 132.

Wintershall, supra note 67.

Ibid at paras 1-5, 18.

Ibid at paras 6-11.

Ibid.

Ibid at para 198.

Ibid at paras 110-57, 160-97.

Ibid at para 160(2). 
Wintershall marks the first time that an arbitral tribunal has denied a claimant's request to access an expedited arbitration process.

Since Wintershall, questions regarding the MFN clause and its application to dispute settlement continue to produce divergent decisions. ${ }^{84}$ Thus, while application of the MFN standard to the substantive disciplines in IIAs is fairly straightforward, an investor's right to pursue arbitration on the basis of the MFN standard remains uncertain. In response to concerns about the potential breadth of application of MFN clauses, some states have begun to negotiate BITs and FIPAs that drastically circumscribe the application of the MFN standard. For example, in response to the divergent jurisprudence on the applicability of MFN clauses to dispute resolution mechanisms, China and Canada agreed in their recently concluded FIPA to circumscribe the application of the MFN clause by expressly excluding its application to dispute resolution mechanisms in other international investment treaties and other trade agreements. ${ }^{85}$

\section{Minimum STANDARD OF TREATMENT AND THE FAIR AND EQUITABLE TREATMENT STANDARD}

In contrast to NT and MFN, the FET standard provides an absolute standard of investment protection. The FET standard plays a central role in many investor-state disputes making it one of the most powerful tools an investor has against host states. It has been applied by investment tribunals in a wide-ranging list of cases involving a variety of government acts. ${ }^{86}$ Given its prominence in investment disputes, one might expect the contours of the FET standard to be well defined based on a well-developed arbitral jurisprudence that would readily allow for application of this standard to the facts of any given dispute. That is not the case however and of all the international investment law disciplines the FET standard is perhaps the most elusive. ${ }^{87}$

In part, this is due to differences in the ways in which the clause is formulated. In some IIAs, the language of the clause is tied to the minimum standard of treatment in international

$84 \quad$ Teinver SA, Transportes de Cercanías SA and Autobuses Urbanos del Sur SA v Argentine Republic (2012), Case No ARB/09/1 (ICSID), Decision on Jurisdiction at para 186 (the Tribunal concluded that the claimant could rely on the MFN clause to make use of more favourable dispute resolution provisions contained in another BIT between Argentina and Australia) see Daimler Financial Services AG $v$ Argentine Republic (2012), Case No ARB/05/1 (ICSID), Award at paras 224, 230-31, 236 (where the Tribunal found that the MFN clause in the Argentina-UK BIT did not apply in such a way as to permit the claimant to avail itself of the dispute resolution provisions of the Argentina-Lithuania BIT).

85 See supra note 32, art 5(3).

$86 \quad$ See e.g. Petrobart Limited v The Kyrgyz Republic (2005), Case No 126/2003 (Arbitration Institute of the Stockholm Chamber of Commerce), Award at 75-82 [Petrobart] (where the investor had obtained a judgment from a Kyrgyz court against a state-owned gas company for amounts owed to Petrobart under a delivery and supply contract. At the request of the political authorities in the Kyrgyz Republic, the Court postponed the execution of that judgment for a few months. During this period, pursuant to a Presidential decree, the state-owned gas company was restructured and declared bankrupt, resulting in Petrobart's inability to collect on its debt judgment or obtain any proceeds from the sale of assets. The Tribunal found a violation of the FET standard articulated in article 10(1) of the ECT as a result of the host state's interference with Petrobart's due process rights); Ioannis Kardassopoulos and Ron Fuchs $v$ Republic of Georgia (2010), Case No ARB/07/15(ICSID), Award at paras 409-52 (where the Tribunal found that assurances of compensation made to the claimants after their concession over Georgia's main oil pipeline was terminated could ground a successful FET claim under the ECT).

87 See PSEG Global, supra note 45 at para 239 (where the Tribunal acknowledges that the FET standard changes from case to case and broadly observes that the standard allows for justice to be done in the absence of other breaches of international law). 
law and in other IIAs it is not. In some cases, tribunals have been able to afford the FET clause a broad interpretation in light of language in the preamble to the IIA, which refers to values such as stability. In other cases there is no such language in the IIA's preamble. Governments, tribunals, and commentators often bemoan the lack of definition of the FET standard and attempt to define the standard's normative content in an effort to establish coherence regarding this popularly invoked discipline. ${ }^{88}$

The parties to NAFTA have made a particular effort to restrictively define the content of the FET clause by the adoption of an interpretative note, which ties the FET standard to the minimum standard of treatment in international law. ${ }^{89}$ NAFTA Awards since the adoption of the Note recognize that the minimum standard of treatment has not been frozen, but that the onus is on the investor to demonstrate that any additional content represents customary international law. ${ }^{90}$

Notwithstanding its elusive nature, arbitral tribunals and commentators generally agree that transparency, stability, and an investor's legitimate expectations play a key role in defining the FET standard. ${ }^{91}$ Indeed, when invoking this standard of protection investors often raise arguments based on the notion that host state governments have taken measures that alter the legal environment in which their investment operates, all to the detriment of the investor and its investment. ${ }^{92}$ In addressing such arguments, recent arbitral decisions introduce some interesting concepts into the FET discussion that are worthy of note and demonstrate the elastic nature of this discipline within the international investment law regime. The discussion below addresses three such concepts: (1) stability and legitimate expectations; (2) creeping violations of the FET standard; and (3) proportionality.

\section{STABILITY AND LEGITIMATE EXPECTATIONS}

Investors in the energy sector, both oil and gas and electricity, frequently seek to argue that the FET clause in a IIA offers them a degree of stability with respect to the domestic

An example of one tribunal's attempt to clarify FET can be found in El Paso, supra note 46 at paras 33079. For commentators' differing views on how to define FET see e.g. Institute for International Law and Justice, "Fair and Equitable Treatment under Investment Treaties as an Embodiment of the Rule of Law,” Working Paper 2006/6 (2006); Charles H Brower, “Investor-State Disputes Under NAFTA: The Empire Strikes Back” (2001) 40:1 Colum J Transnat'l L 43; Rudolf Dolzer, "Fair and Equitable Treatment: A Key Standard in Investment Treaties” (2005) 39:1 International Lawyer 87.

See NAFTA Free Trade Commission, " North American Free Trade Agreement Notes of Interpretation of Certain Chapter 11 Provisions," online: SICE <http://www.sice.oas.org/tpd/nafta/Commission/ CH11understanding_e.asp>. The Neer Arbitration Award (LFH Neer and Pauline Neer v United Mexican States (1926), 4 Reports of International Arbitral Awards 60 at 61-62) provides the classical definition of the minimum standard. State conduct violates the minimum standard to the extent that it amounts to "an outrage, to bad faith, to wilful neglect of duty, or to an insufficiency of governmental action so far short of international standards that every reasonable and impartial man would readily recognize its insufficiency."

See e.g. Glamis, supra note 26.

See Dolzer \& Schreuer, supra note 50 at $133-48$.

In the energy context, many such cases have been initiated against Argentina since its economic crisis in 2001 (see e.g. CMS Gas Transmission Company v Argentine Republic (2005), Case No ARB/01/8 (ICSID), Award [CMS, Award]; LG\&E, supra note 22; Enron, Award, supra note 41; Sempra, supra note 41; Total SA, supra note 19; El Paso, supra note 46). Investors' legitimate expectations in the context of the FET standard have also been raised in cases against Ecuador over the availability of valueadded tax refunds (see e.g. OEPC I, supra note 43; EnCana Corporation v Republic of Ecuador (2006), Case No UN3481 (London Court of International Arbitration), Award. 
laws of the host state. At the same time, it is broadly accepted that states that are party to such agreements

do not thereby relinquish their regulatory powers nor limit their responsibility to amend their legislation in order to adapt it to change and the emerging needs and requests of their people in the normal exercise of their prerogatives and duties. Such limitations upon a government should not lightly be read into a treaty which does not spell them out clearly nor should they be presumed. ${ }^{93}$

In general the jurisprudence suggests that an investor will only succeed in a claim that the host state has violated its legitimate expectations or a claim to stability if it can point to some particular promise or undertaking. ${ }^{94}$

In the context of NAFTA, the Tribunal in Mobil Investments Canada Inc. v. Canada ${ }^{95}$ rejected the stability arguments of the investors with respect to domestic benefits requirements imposed by Canadian law. The Tribunal emphasized that:

Article 1105 is not, and was never intended to amount to, a guarantee against regulatory change, or to reflect a requirement that an investor is entitled to expect no material changes to the regulatory framework within which an investment is made. Governments change, policies change and rules change. These are facts of life with which investors and all legal and natural persons have to live with. ${ }^{96}$

That did not mean that article 1105 could never support a claim to stabilization. But in order to succeed a claimant would have to show that the changes to the domestic law were "grossly unfair or discriminatory" 97 or that such changes were inconsistent with a specific promise or representation made by the state. That was not the case here. There were no representations that the benefits requirement would not change, and the existing benefits plans were not themselves contracts.

\section{CREEPING VIOLATIONS OF FET}

As noted above, El Paso is one of the many cases stemming from measures taken by Argentina during its financial crisis over a decade ago. El Paso's FET argument was that the legal rights granted by the government of Argentina through regulatory frameworks in the country's electricity and hydrocarbon sector at the time of its investment were important to El Paso's decision to invest in Argentina. In its view, those rights were eviscerated by regulatory changes made in Argentina during its economic crisis thereby causing a FET violation. ${ }^{98}$ The Tribunal found that none of the individual measures taken by Argentina from

Total SA, supra note 19 at para 115.

Ibid at para 119 .

Mobil Investments Canada Inc and Murphy Oil Corporation v Canada (2012), Case No ARB(AF)/07/4

(ICSID), Decision on Liability and Principles of Quantum [Mobil].

Ibid at para 153 .

Ibid at para 153. See also PSEG Global, supra note 45 where a FET-based legitimate expectations argument failed in the context of frustrated negotiations over a proposed BOT (build, operate, transfer) project to construct a new thermal base load (lignite) power plant. The Tribunal however did accept three different FET-based arguments: (1) serious administrative negligence and inconsistency in handling the negotiations, (2) abuse of authority in applying domestic laws, and (3) "roller-coaster" changes in law policy - all during the course of the negotiations. 
December 2001 onward following its financial crisis constituted a breach of the FET clause. ${ }^{99}$ However, the Tribunal concluded that the cumulative effect of those measures constituted a breach of the FET standard as there was "a total alteration of the entire legal setup for foreign investments" in violation of "a special commitment of Argentina that such a total alteration would not take place." ${ }^{100}$ Referring to the concept of "creeping expropriation," the Tribunal considered the measures at issue in this case to be a "creeping violation of the FET standard," which it described as "a process extending over time and comprising a succession or an accumulation of measures which, taken separately, would not breach that standard but, when taken together, do lead to such a result.”" ${ }^{101}$ Having so found, the Tribunal appears, quite unexpectedly, to have broadened the circumstances in which an investor could assert violations of this already uncertain discipline. Along with the potential widening of claims available to investors under the FET standard, there is a growing recognition that FET includes the concept of reasonableness and proportionality. ${ }^{102}$ Proportionality was the focus of a recent decision involving two petroleum companies and Ecuador.

\section{PROPORTIONALITY}

In Occidental Petroleum Corporation, Occidental Exploration and Production Company $v$. The Republic of Ecuador ${ }^{103}$ the two claimants sought more than US\$3 billion after a contract to explore and exploit oil (the PSA) was severed by Ecuador. The claimants in this case had entered into a farmout agreement with a subsidiary of the Alberta Energy Company (AEC) in exchange for payments that would contribute to capital investments and operating costs in an Ecuadorian oil field. ${ }^{104}$ That farmout agreement and significant internal political pressure eventually led to Ecuador's Minister of Energy and Mines cancelling the PSA with the claimants on the grounds that the farmout agreement amounted to an unauthorized transfer or assignment and an unauthorized consortium, as well as a number of technical infractions committed by the claimants. ${ }^{105}$ The claimants argued that the annulment of the PSA was both a breach of FET and an unlawful expropriation. ${ }^{106}$ While the Tribunal found that OEPC had breached both the terms of its PSA with Ecuador and the terms of the hydrocarbons law when it entered into the farmout agreement without obtaining the prior approval of the Minister of Energy, ${ }^{107}$ the Tribunal nonetheless determined that Ecuador had acted inequitably and unfairly.

In so finding, the Tribunal recognized the principle of proportionality as part of the content of the FET standard under the terms of the US-Ecuador BIT. Specifically, the Tribunal concluded that Ecuador had breached "the overriding principle of proportionality"

Ibid at paras 390-402.

Ibid at para 517.

Ibid at para 518.

See ibid at para 373. See also Continental Casualty Company v Argentine Republic (2008), Case No ARB/03/9 (ICSID), Award at para 258 [Continental Casualty].

Occidental Petroleum Corporation, Occidental Exploration and Production Company v Republic of Ecuador (2012), Case No ARB/06/11 (ICSID), Award [OEPC II].

Ibid at paras 127-38.

Ibid at paras 191-200.

Ibid at paras 201-43.

Ibid at paras 297-383. 
which requires that the goals of the state "must be balanced against the Claimants' own interests and against the true nature and effect of the conduct being censured."108

In this case, the Tribunal considered that the state had suffered no real harm. The state interest was in ensuring that the operation of the oilfield was not entrusted to an unsuitable party, but that was not an issue here since AEC had already been approved as an operator of another property. ${ }^{109}$ Thus "the price paid by the Claimants — total loss of an investment worth many hundreds of millions of dollars - was out of proportion to the wrongdoing alleged against OEPC, and similarly out of proportion to the importance and effectiveness of the 'deterrence message' which the Respondent might have wished to send to the wider oil and gas community." 110 Somewhat surprisingly, the Tribunal spent little time on the question of whether the principle of proportionality was part of the FET standard as articulated in the language of this particular treaty. While the Tribunal quotes the FET provision in the US-Ecuador BIT, it quickly moves to a discussion of proportionality within ICSID cases generally. ${ }^{111}$ Thus, the Tribunal simply concludes that Ecuador's cancellation of its contract with OEPC breached Ecuadorian law, customary international law, and the Treaty. As to the latter, the Tribunal expressly finds a failure by Ecuador to honour its article II.3(a) obligation to accord FET to the claimants' investment, and to accord them treatment no less than that required by international law. ${ }^{112}$

\section{E. THE DUTY Not TO EXPROPRIATE}

One of the primary protections in a IIA is the guarantee that foreign investors will not fall victim to uncompensated expropriations. While the language of such clauses varies, they generally ensure investors are protected against direct takings (or direct expropriations), which involve the transfer of title or outright physical seizure of an investor's property. Outright physical seizures may be rare but still happen. ${ }^{113}$

Foreign investors are also protected from measures that fall short of direct takings but are considered expropriations because they permanently destroy the economic value of the investment or deprive the owner of its ability to manage, use, or control its property in a meaningful way (that is, indirect expropriations). ${ }^{114}$ In recent years, questions about indirect

\footnotetext{
$108 \quad$ Ibid at para 450.

$109 \quad$ Ibid at para 447.

$110 \quad$ Ibid at para 450.

$111 \quad$ Ibid at paras 402-409.

$112 \quad$ Ibid at para 452.
}

113 Burlington, supra note 23. In this case the majority denied Burlington's claims that Ecuador's taxation measures brought about an expropriation, but the entire panel concluded that Ecuador's decision to take control of Burlington's well sites when it suspended operations in response to Ecuador's seizure and sale of its production did amount to an expropriation since it deprived Burlington not only of its oil production share but of the means of production (at para 530). Thus while Burlington still had its investment (its share of the production sharing contract (PSC)), the PSC had "no value without possession of the oil fields and access to the oil."

114 For an overview of expropriation clauses in treaty provisions see UNCTAD, Expropriation: UNCTAD Series on Issues in International Investment Agreements II (New York: United Nations, 2012) at 5-17 [UNCTAD, Expropriation]. See also NAFTA, supra note 3, art 1110 which provides that:

No Party may directly or indirectly nationalize or expropriate an investment of an investor of another Party in its territory or take a measure tantamount to nationalization or expropriation of such an investment (“expropriation”), except:

(a) for a public purpose;

(b) on a non-discriminatory basis;

(c) in accordance with due process of law and Article 1105(1); and

(d) on payment of compensation in accordance with paragraphs 2 through 6 . 
expropriations have gained prominence in the arbitral jurisprudence and scholarship dealing with this standard of protection. One of the more challenging problems has been the matter of establishing an indirect expropriation without impeding the right of a state to regulate in the public interest. To that end, arbitral tribunals have articulated a number of factors to be used when assessing whether an indirect expropriation has occurred. Those factors are discussed below with reference to relevant jurisprudence in the energy sector.

\section{IMPACT OF THE MEASURE}

To be considered expropriatory, a measure or a series of measures must have a destructive and long-lasting effect on the economic value of the investment and its benefit to the investor. To that end, there are three key questions to examine when considering this factor in the context of an indirect expropriation: (1) whether the measure resulted in a total or neartotal destruction of the investment's economic value; (2) whether the investor has been deprived of the control over the investment; and (3) whether the effects of the measure are permanent.

\section{a. Destruction of Economic Value}

The mere fact that a measure or a series of measures has an adverse effect on the economic value of the investment does not necessarily imply that an indirect expropriation has occurred. The arbitral decision in Total S.A. supports this conclusion. ${ }^{115}$ In this case, Total argued that measures taken by Argentina under its emergency law passed in response to its 2001 economic crisis amounted to an indirect expropriation of its investments in Argentina's gas transportation industry. In rejecting Total's arguments regarding the adverse economic impact of Argentina's measures on the value of its investment, the Tribunal determined that Total had not shown that the negative economic negative impact of Argentina's measures had deprived its investment of all or substantially all its value. ${ }^{116}$

Particularly notable in this context is the award in Burlington, ${ }^{117}$ where the majority held that a new tax that was designed to appropriate to the state the benefit of increased world oil prices did not amount to an expropriation. It was not an expropriation when the tax was designed to recover 50 percent of incremental revenues, and it was not even an expropriation when the tax was increased to recover 99 percent of the incremental revenues. The majority reasoned that while the law substantially diminished the profits that would flow to Burlington, the investment was still not rendered "worthless and unviable."”118

Total SA, supra note 19 at paras 196-97.

Ibid. This finding is consistent with a series of cases addressing indirect expropriation in the wake of Argentina's economic crisis. See e.g. LG\&E, supra note 22 at para 200 where the Tribunal stated that "the effect of the Argentine State's actions has not been permanent on the value of the Claimants' shares, and Claimants' investment has not ceased to exist. Without a permanent, severe deprivation of LG\&E's rights with regard to its investment, or almost complete deprivation of the value of LG\&E's investment, the Tribunal concludes that these circumstances do not constitute expropriation.” See also BG Group PLC v Argentine Republic, UNCITRAL, Award (24 December 2007) at para 268-70 [BG Group PLC]; Enron, Award, supra note 41 at para 246. Burlington, supra note 23.

Ibid at para 456. Arbitrator Orrego Vicuňa would have found an expropriation at both levels of taxation (see Burlington Resources Inc v Republic of Ecuador (2010), Case No ARB/08/5 (ICSID), Dissenting Opinion of Arbitrator Orrego Vicuña [Burlington, Dissent]). The majority also held at paras 469-85 that Ecuador's decision to seize produced oil and sell it in satisfaction of Burlington's tax liability was not an expropriation of Burlington's investment even though the oil was sold to a state entity at well below 


\section{b. Loss of Control}

In addition to destruction of an investment's economic value, an indirect expropriation may occur if an investor loses control of its investment. Such a loss of control could come in the form of lost ownership or management rights even if legal title to the investment is not affected. An alternative to considering the economic destruction of an investment, loss of control is a useful factor to consider in cases where the investment is a company or shareholdings in a company. Thus, in El Paso, the Tribunal indicated that in order to determine whether an interference is sufficiently restrictive to amount to an "indirect" expropriation, loss of control, rather than the mere loss of value, is the crucial element. The El Paso tribunal stated that " [i]t is generally accepted that the decisive element in an indirect expropriation is the 'loss of control' of a foreign investment, in the absence of any physical taking," "119 and that "a mere loss in value of the investment, even if important, is not an indirect expropriation.”"120

\section{c. Permanence}

In order to constitute an indirect expropriation, the measure should be definitive and permanent. A measure that leads to a temporary devaluation or loss of control in the investment is usually not viewed as expropriatory. Numerous tribunals have recognized permanence as one of the key factors used to determine whether an indirect expropriation has taken place. ${ }^{121}$ Thus, in $L G \& E$, the Tribunal opined that, "the expropriation must be permanent, that is to say, it cannot have a temporary nature."122 Notwithstanding its stated importance as a factor used to ground indirect expropriation claims, there is no set timeframe, which if surpassed will inevitably lead to a successful expropriation claim. Indeed, the application of this factor to expropriation cases is fact-specific.

\section{LEGITIMATE EXPECTATIONS AND STABILITY}

Another relevant factor an arbitral tribunal will consider when determining whether a measure or series of measures amounts to an indirect expropriation is the foreign investor's expectations with respect to acts taken by a host state. In other words, a tribunal will evaluate whether the measure at issue interferes with an investor's reasonable investment-backed expectations. For some tribunals, legitimate expectations need not be based on specific and explicit undertakings or representations of the host state. Implicit state assurances, coupled with the foreign investor's assumptions, have been sufficient to ground claims of indirect expropriation. ${ }^{123}$ By contrast, other tribunals have required investors to base their legitimate

the market price. The majority was at pains to emphasize that in considering whether or not there is an expropriation, it is important to examine the investment as a whole. At this stage in the proceedings (at para 470) the forcible appropriation of taking concerned only the oil. El Paso, supra note 46 at para 245.

Ibid at para 249. See also CMS, Award, supra note 92 at para 263 (where the investment in a gas transportation company) suffered from a significant decrease in value, but the tribunal dismissed the expropriation claim in light of the fact that the investor retained full ownership and control of the shareholding).

See e.g. Técnicas Medioambientales Tecmed SA v United Mexican States (2003), Case No ARB (AF)/00/2 (ICSID), Award at para 116 [Tecmed]; SD Myers, supra note 61 at paras 287-88. Supra note 22 at para 193.

Azurix, supra note 40 at paras 316-22. 
expectations on specific commitments made by the host state. ${ }^{124}$ Despite discrepancies regarding the appropriate basis for claims of legitimate expectations in the expropriation context, scholars note that tribunals have used a demanding threshold when evaluating such claims. ${ }^{125}$ The most recent decision addressing legitimate expectations in the context of indirect expropriation claims appears to support this general proposition. While the case is outside the energy context, its consideration of legitimate expectations is still instructive.

Grand River Enterprises Six Nations v. United States of America ${ }^{126}$ was a NAFTA dispute initiated by Canadian claimants, including individual members of the Six Nations of America, against the US Government. The dispute revolved around the 1998 Master Settlement Agreement (MSA), a regulation concluded between major US tobacco companies and states within the US on tobacco marketing and tobacco-related public health spending. ${ }^{127}$ The claimants were involved in the manufacture and sale of tobacco products in Canada and the US. ${ }^{128}$ The Tribunal rejected the claims of most of the claimants for failing to establish that they satisfied the definition of investment in article 1139 of NAFTA. ${ }^{129}$ However, the Tribunal did consider the claims made by one of the individual claimants (Arthur Montour) in the case. In its determination of whether the disputed measure constituted an indirect expropriation of Montour's investment, the Tribunal took into consideration the investor's reasonable expectations. Montour argued that, as a member of the First Nations in North America (a protected and sovereign group of peoples) he reasonably expected that his activities were immune from the MSA. ${ }^{130}$ The Tribunal rejected those arguments because of uncertainties regarding the MSA's application to the investor and his activities. ${ }^{131}$ In particular, the Tribunal noted that "[o]rdinarily, reasonable or legitimate expectations of the kind protected by NAFTA are those that arise through targeted representations or assurances made explicitly or implicitly by a state party."132

Connected to legitimate expectations are arguments related to stability (that is, that the regulatory environment in the host state has unexpectedly changed). However, tribunals have recognized that states have the right to regulate and thereby alter the environment in which an investor operates. In Waste Management, Inc. v. United Mexican States ${ }^{133}$ the Tribunal stated, "it is not the function of the international law of expropriation ... to eliminate the normal commercial risks of a foreign investor." ${ }^{\prime 34}$ As a result, investors remain exposed to a variety of risks in the host state in which they operate, including the risk of changes in a host state's regulatory environment. The degree to which an investor will be exposed to changes in a host state's regulatory environment will depend on a number of factors,

Methanex Corporation v United States of America, UNCITRAL, Final Award (3 August 2005) at Part IV, Chapter D, para 7 [Methanex].

125 August Reinisch, "Expropriation” in Peter Muchlinski, Federico Ortino \& Christoph Schreuer, eds, The Oxford Handbook of International Investment Law (Oxford: Oxford University Press, 2008) 407 [Muchlinski, Oxford Handbook]. Grand River Enterprises Six Nations, Ltd v United States of America, UNCITRAL, Award (12 January 2011) [Grand River Enterprises]. Ibid at paras 8-21.

Ibid at paras 22-26.

Ibid at paras 76-106.

Ibid at paras 128-32.

Ibid at para 142.

Ibid at para 141 [emphasis added].

Waste Management, Inc v United Mexican States (2004), Case No ARB(AF)/00/3 (ICSID), Award. Ibid at para 77. See also Continental Casualty, supra note 102 at para 258. 
including the type of investment, the regulatory context in which the investment is made, and the characteristics and the institutional particularities of the host country. ${ }^{135}$

\section{NATURe, ObJectives, AND Character of The MeAsure}

In addition to the above factors, increasing attention is being paid to the nature, objectives, and character of measures challenged under the indirect expropriation doctrine. Such considerations are particularly important in distinguishing between an indirect expropriation and the valid regulatory acts of a host state, which are not subject to compensation. ${ }^{136}$ Arbitral tribunals have recognized the capacity of states to regulate in the public interest. Thus, in Methanex, ${ }^{137}$ a NAFTA panel found that a California ban on a gasoline additive (MTBE) was deemed to be a lawful non-compensable regulation. Specifically, the tribunal stated that

as a matter of general international law, a non-discriminatory regulation for a public purpose, which is enacted in accordance with due process and, which affects, inter alios, a foreign investor or investment is not deemed expropriatory and compensable unless specific commitments had been given by the regulating government to the then putative foreign investor contemplating investment that the government would refrain from such regulation. ${ }^{138}$

Many arbitral tribunals have expressed similar sentiments about the regulatory powers states have to adopt, in a non-discriminatory manner, regulations for legitimate public purposes. ${ }^{139}$ While non-discrimination is specifically mentioned as a standard of protection that applies to a host state's regulatory powers, it is not the only applicable standard of protection limiting such state powers. A host state's general regulatory rules and measures implemented pursuant to those rules are subject to all of the standards of protection in a IIA. As a result, recent arbitral decisions in the energy sector have focused on balancing a host state's right to regulate in the public interest with the protection of investor's rights by incorporating notions of reasonableness or proportionality into analyses regarding the existence of an indirect expropriation.

UNCTAD, Expropriation, supra note 114 at 76.

Recent IIAs have begun to explicitly include these criteria in assessments of government measures challenged as indirect expropriations. See e.g. Canada-Romania BIT, UNCTAD, “Agreement between the Government of Canada and the Government of Romania for the Promotion and Reciprocal Protection of Investments" (2009), online: UNCTAD < http://unctad.org/sections/dite/iia/docs/bits/canada_rom ania.pdf>, Annex B:

Clarification of indirect expropriation, which provides:

(b) The determination of whether a measure or series of measures of a Contracting Party constitute an indirect expropriation requires a case-by-case, fact-based inquiry that considers, among other factors:

(iii) The character of the measure or series of measures, including their purpose and rationale. Methanex, supra note 124 .

Ibid at para 7.

See e.g. Feldman, supra note 60 at para 103; SD Myers, supra note 61 at para 281; Saluka, supra note 16 at paras 255, 262; Suez Sociedad General de Aguas de Barcelona SA and InterAgua Servicios Integrales del Agua SA v Argentine Republic (2010), Case No ARB/03/17 (ICSID), Decision on Liability at para 147. 


\section{PROPORTIONALITY}

Having found that the claimant failed to establish a substantial deprivation of the value of the investment, the tribunal in Total SA also found that Argentina's pesification was "a bona fide regulatory measure of general application, which was reasonable in light of Argentina's economic and monetary emergency and proportionate to the aim of facing such an emergency" and thus did not amount to a measure equivalent to expropriation. ${ }^{140}$ Proportionality worked in favour of the investor in OEPC II. ${ }^{141}$ The Tribunal rejected Ecuador's argument to the effect that termination of a contract for breach in accordance with its terms was not an expropriation. The Tribunal held, given its findings as to the absence of proportionality in cancelling OEPC's participation agreement in the context of OEPC's FET argument, that the sanction that Ecuador imposed in this case was a measure "tantamount to expropriation.”" ${ }^{42}$ Once again, as with the FET argument, the Tribunal offered little by way of legal analysis to support this conclusion, contenting itself with quoting the relevant article of the BIT (article III), and referring to one of the principal NAFTA expropriation cases Metalclad v. United Mexican States. ${ }^{143}$

\section{F. Full Protection ANd Security}

Most IIAs contain clauses which promise foreign investors "full protection and security," “constant protection and security," or "continuous protection and security.” For a long time, such clauses went relatively unnoticed in investor-state jurisprudence. Since 2004, however, the clause has increasingly become the subject of arbitral consideration. ${ }^{144}$ Tribunals largely agree that the full protection and security standard imposes an obligation of vigilance and due diligence on a host state to prevent wrongful injuries to foreign investors or at least exercise due diligence to punish such injuries. That obligation is not absolute and requires that a state act reasonably. ${ }^{145}$ Some of the most contested issues with respect to the standard of full protection and security are whether or not it extends beyond the physical security of the investor or its investment is compromised, its relationship to other substantive disciplines within IIAs, and its relationship to customary international law. Some recent arbitral decisions involving investments in the energy sector arising out of Argentina's economic crisis are illustrative of these controversies. In each of these cases, the tribunal was asked to interpret similarly worded full protection and security clauses. The claimants' arguments were rooted in allegations that measures taken by Argentina in response to its financial crisis compromised the legal security of foreign investors and their investments.

Total SA, supra note 19. See also El Paso, supra note 46 at para 197.

Supra note 103.

Ibid at para 455.

Metalclad v United Mexican States (2000), Case No ARB(AF)/97/1 (ICSID), Award. Note as well that the BIT in question does not use the language of "tantamount to expropriation" (which comes from NAFTA, article 1110).

See Mahnaz Malik, The Full Protection and Security Standard Comes of Age: Yet Another Challenge for States in Investment Treaty Arbitration? (2011), online: International Institute for Sustainable Development <http://www.iisd.org/pdf/2011/full_protection.pdf> at 1.

Dolzer \& Schreur, supra note 50 at 149. 
In Enron, ${ }^{146}$ the Tribunal acknowledged that the full protection and security standard may encompass the stability of the legal framework and legal security of an investment. ${ }^{147}$ However, the Tribunal also acknowledged that analytical difficulties arise with such an extension of the full protection and security standard. In particular, the Tribunal stated:

There is no doubt that historically this particular standard has been developed in the context of physical protection and security of the company's officials, employees and facilities. The Tribunal cannot exclude as a matter of principle that there might be cases where a broader interpretation could be justified ... [but] then [it becomes] difficult to distinguish [such situation from one] resulting in the breach of fair and equitable treatment, and even from some form of expropriation. ${ }^{148}$

Avoiding such analytical redundancies, the Tribunal in BG Group $P I C^{149}$ found that full protection and security could only be violated if the physical security of the investor or its investment is compromised. ${ }^{150} \mathrm{~A}$ more recent decision considering the same treaty provision at issue in El Paso further narrows the application of the full protection and security standard.

In El Paso, ${ }^{151}$ the Tribunal determined that the full protection and security standard is linked to the traditional obligation to protect aliens under customary international law. ${ }^{152}$ Additionally, the Tribunal characterized full protection and security as a "residual obligation" available only in cases where the acts challenged may not be attributable to a government, but to a third party. ${ }^{153}$ As a result, the Tribunal rejected the claimant's arguments regarding full protection and security because all of the impugned acts allegedly violating the full protection and security standard were directly attributable to Argentina. ${ }^{154}$

\section{G. DOMESTIC REQUIREMENTS}

In addition to the core disciplines of IIAs, individual IIAs may include additional disciplines such as the obligation not to impose domestic performance requirements on foreign investors. For example article 1106 of NAFTA provides in part as follows:

Enron, Award, supra note 41.

Ibid at paras 286-87. In this case the Tribunal was speaking about the full protection and security standard articulated in article II(2)(a) of the US-Argentine BIT, which states: "Investment shall at all times be accorded fair and equitable treatment, shall enjoy full protection and security and shall in no case be accorded treatment less than that required by international law." (UNCTAD, "Treaty between United States of America and The Argentine Republic Concerning the Reciprocal Encouragement and Protection of Investment” (signed 14 November 1991, entered into force 20 October 1994), online: UNCTAD < http://unctad.org/sections/dite/iia/docs/bits/argentina_us.pdf >.)

Sempra, supra note 41 at paras 323 . A similar conclusion was reached by the arbitral tribunal considering the same BIT provision in Enron, Award, supra note 41 at para 286. See also Azurix, supra note 40 at para 408 . Some arbitral tribunals have incorporated the full protection and security standard within the FET protection (see e.g. Total SA, supra note 19 at para 343).

BG Group PlC, supra note 116.

Ibid at para 326. In this case the arbitral tribunal was interpreting the full protection and security standard outlined in article 2(2) of the UK-Argentine BIT, the relevant portion of which provides: "Investments of investors of each Contracting Party shall at all times be accorded fair and equitable treatment and shall enjoy protection and constant security in the territory of the other Contracting Party." (UNCTAD, "Agreement between the Government of the United Kingdom of Great Britain and Northern Ireland and the Government of the Republic of Argentina for the Promotion and Protection of Investments" (1991), online: UCTAD <http://unctad.org/sections/dite/iia/docs/bits/uk_argentina.pdf>.) El Paso, supra note 46.

Ibid at para 522.

Ibid.

Ibid at para 524. 
1. No Party may impose or enforce any of the following requirements, or enforce any commitment or undertaking, in connection with the establishment, acquisition, expansion, management, conduct or operation of an investment of an investor of a Party or of a non-Party in its territory: to achieve a given level or percentage of domestic content; to purchase, use or accord a preference to goods produced or services provided in its territory, or to purchase goods or services from persons in its territory.

This article, and an accompanying reservation by Canada, was the subject of detailed analysis in Mobil. ${ }^{155}$ In that case, Mobil and Murphy successfully argued that a domestic benefits measure introduced by the Canada Newfoundland Offshore Petroleum Board under the terms of Canada-Newfoundland Atlantic Accord Implementation Act ${ }^{156}$ was inconsistent with article 1106 of NAFTA. The measure in question, the Guidelines for Research and Development Expenditures, requires operators to make certain levels of expenditure on Research \& Development (R \& D) matters for each of the exploration, development, and production phases of a project. ${ }^{157}$ The Board calculated these expenditure targets based on Statistics Canada data for average R \& D expenditures in the industry. In default thereof, operators were required to contribute any shortfall to a Board-administered R \& D fund. The measures were made enforceable by making them a condition of the operator's Production Operations Authorization (POA).

The Tribunal concluded unanimously that the Guidelines were prima facie inconsistent with the requirements of article 1106 . This preliminary conclusion could hardly be controversial. Much more surprising however was the conclusion of the majority that the Guidelines were not excepted from the application of Article 1106 by the terms of a reservation that Canada had taken. Under the system of reservations in chapter 11, article 1108 allows each party to frame a reservation or set of reservations to, inter alia, article 1106. One of Canada's reservations to article 1106 was listed as the Canada-Newfoundland Atlantic Accord Implementation Act. ${ }^{158}$ A reservation must list the measure, describe the nature of the requirement, and specify any relevant phase out period for the reservation. The scope of the reservation is expressed to extend to both "the continuation or prompt renewal" of the non-conforming measure ${ }^{159}$ (provided that such continuation or renewal "does not decrease the conformity of the measure") and any subordinate measure designed to implement the main measure. ${ }^{160}$

Mobil, supra note 95.

Canada-Newfoundland Atlantic Accord Implementation Act, SC 1987, с 3 [Accord Act].

Canada-Newfoundland and Labrador Offshore Petroleum Board, Guidelines for Research and Development Expenditures (October 2004), online: C-NLOPB <http://www.cnlopb.nl.ca/pdfs/ibguide/ guidelines_for_research_and_development_expenditures.pdf $>$ [Guidelines].

Additional measures included the Canada-Nova Scotia Offshore Petroleum Resources Accord Implementation Act, SC 1998, c 35, and the Canada Oil and Gas Operations Act, RSC 1985, c O-7. NAFTA, supra note 3, arts 1108(b)-(c).

The term "subordinate measure" is effectively defined in NAFTA, supra note 3, Annex I as a measure "adopted or maintained." 
In this case it was clear that the Guidelines were not themselves listed as "the measure" and thus could only fall within the protection of the measure if they were a subordinate measure, which meant that they had to be "adopted or maintained under the authority of and consistent with the measure." One way to answer that question was to resort to domestic law and ask whether the Guidelines were validly adopted under the federal Accord Act. ${ }^{161}$ As it happens, that issue had already been litigated and the majority of the Newfoundland Court of Appeal had concluded that the Board's decision to adopt the Guidelines could not be impugned. ${ }^{162}$ However, the majority of the Tribunal took the view that this was not a conclusive answer and that any new subordinate measure had to be consistent not only with the main measure but also with any earlier subordinate measures that might also have been adopted under the authority of the main measure. In this case, the earlier subordinate measures included the various project specific benefit plans, which had been approved by the Board in relation to the Hibernia and Terra Nova projects. Since those plans had a narrower ambit than the Guidelines, the majority was of the view that the Guidelines were not consistent with the main measure as qualified by the previous subordinate measures. As a result, the Guidelines did not qualify as a covered subordinate measure. Consequently, the Guidelines were not protected by Canada's reservation and accordingly Canada was in breach of its obligation under article 1106 not to impose domestic performance requirements. In our view the test that the majority sets out for a measure to qualify as a legitimate subordinate measure is extraordinarily demanding and seriously undermines the intentional unilateral power of a contracting party to make reservations to this broad reaching discipline. The view of the dissenting arbitrator, Phillipe Sands, seems more consistent with the unilateral nature of the reservation power. ${ }^{163}$

\section{H. Umbrella Clause}

An umbrella clause is a provision in a IIA that guarantees the observation of obligations between a host state and an investor. Such clauses are not found in every IIA. For example, there is no such clause in NAFTA. The ECT version of the umbrella clause reads as follows: "Each Contracting Party shall observe any obligations it has entered into with an Investor or an Investment of an Investor of any other Contracting Party." 164 Umbrella clauses are particularly significant in those economic sectors (such as the energy sector) where there might be significant state involvement either as owner of the resource (for example, petroleum) or as owners of significant facilities (for example, generating assets or transmission assets).

Hibernia Management and Development Company Ltd and Petro-Canada v Canada-Newfoundland Offshore Petroleum Board, 2008 NLCA 46, 297 DLR (4th) 65. The Court held that the applicable standard of review was reasonableness.

This line of reasoning is pursued in more detail in Bankes, "From Regulatory Chill," supra note 37. ECT, supra note 5, art 10(1). See also Annex IA of the ECT, which indicates that four states opted out of this provision in the ECT (Norway, Canada, Australia, and Hungary). Of those states, Norway, Canada, and Australia have never ratified the ECT. Umbrella clauses in other IIAs may be worded a little differently and guarantee the observance of the commitments made by a host state toward a foreign investor and its investments (see e.g. article 11 of the Switzerland-Paraguay BIT referenced at para 68 of SGS Société Générale de Surveillance SA v The Republic of Paraguay (2012), Case No ARB/07/29 (ICSID), Award). Despite such differences, the controversies surrounding the clauses application remain the same. 
The most controversial issue in relation to the umbrella clause is whether, and under what circumstances, it internationalizes a dispute that would otherwise be considered a contractual dispute to be litigated in the domestic courts. ${ }^{165}$ The following discussion provides a brief overview of the factors to consider when applying an umbrella clause.

\section{ATTRIBUTION}

An umbrella clause only guarantees obligations or commitments made by the host state. Therefore, if a private party within a host state breaches a commitment to an investor, such a breach may ground contractual claims, but not a claim of treaty violation. This proposition led to a dismissal of umbrella clause claims in Amto. ${ }^{166}$ In this case, the claimant had purchased a majority stake in a Ukraine company called EYUM-10, which serviced the Ukraine's state-owned nuclear power company, Energoatom. ${ }^{167}$ Outstanding debt owed to EYUM-10 by the ailing nuclear power company was the basis for Amto's case against the Ukraine. ${ }^{168}$ Amto argued that Ukraine was liable for the EYUM-10's debts by virtue of commitments made in its domestic investment legislation which the umbrella clause of article 10(1) of the ECT raised to an arbitral cause of action. The Tribunal rejected that claim considering instead that a separate legal entity (EYUM-10) made the contractual undertakings regarding outstanding debt payments. Thus the umbrella clause was said to be inapplicable in this case. ${ }^{169}$

\section{PRIVITY}

Some arbitration panels have used the doctrine of privity to limit the application of the umbrella clause. The issue of privity arises in situations where the party to whom the promise or undertaking (or obligation entered into) is made is incorporated under the laws of the host state. The investor may have decided to structure the arrangement this way, or it may be a requirement of domestic law that only a domestically incorporated company is eligible to hold a particular privilege (for example, a production licence). Whatever the reason, it seems fairly clear that the domestic entity cannot itself sue on the umbrella clause since only an investor of the other contracting party can have a cause of action under an IIA. While the international investor in the domestic entity will still be able to take advantage of many of the disciplines of the IIA, the jurisprudence suggests that it will not likely be able to take advantage of the umbrella-clause-protected undertaking because it is not privy to that undertaking. The Burlington award provides a recent example of this. ${ }^{170}$ In that award, the

For an overview of the evolution of the umbrella clause and its consideration by arbitral tribunals see Dolzer \& Schreuer, supra note 50 at 153-62.

Limited Liability Company Amto v Ukraine (2008), Case No 080/2005 (Arbitration Institute of the Stockholm Chamber of Commerce) Final Award [Amto].

Ibid at $\S \S 15-20$.

Ibid at $\S \S 21-25$.

Ibid at §§ 109-10; see Al-Bahloul, supra note 12 at paras 263-68 (where, despite having to dismiss most of Mr. Al-Bahloul's treaty claims, the Tribunal decided that the Tajik Republic's refusal to issue exploration licenses violated contractual obligations entered into between Tajikistan and the claimant for intended to facilitate oil and gas exploration activities. Consequently Tajikistan was found to have breached the so-called umbrella clause of the ECT).

Burlington, supra note 23. The language of the umbrella clause in the Ecuador-US BIT was to the effect that "Each Party shall observe any obligation that it may have entered into with regard to investments." (UNCTAD, "Treaty between the United States of America and the Republic of Ecuador concerning the Encouragement and Reciprocal Protection of Investment” (27 August 2003), online: UNCTAD < http:// unctad.org/sections/dite/iia/docs/bits/us_ecuador.pdf > .) 
majority took the view that the relevant undertaking (the promise to apply the balancing provisions of the Production Sharing Contract (PSC) in the event of a change in the tax regime) was a promise made to the entity that was a party to the PSC, which was the claimant's local subsidiary, Burlington Oriente. As a result, and after canvassing a series of arbitral awards dealing with the issue, the majority concluded that it had no jurisdiction to consider the umbrella clause issues. ${ }^{171}$

\section{SCOPE OF PROTECTION}

Even if one can establish that a host state has made commitments to foreign investors, arbitral tribunals remain uncertain about the scope of protection offered by the umbrella clause and, in particular, whether it elevates all contractual breaches by the state to the level of a treaty breach. Some tribunals have included contractual obligations such as payment obligations ${ }^{172}$ within the scope of an umbrella clause while others confine the ambit of the clause to obligations assumed through law or regulation. ${ }^{173}$ Other awards confine the umbrella clause to the exercise of sovereign authority by the state which breaches some undertaking made to the investor. ${ }^{174}$

In conclusion, umbrella clauses continue to be controversial. Some states, including Canada, resist their inclusion in IIAs. Where such clauses are included, arbitral tribunals show little consistency in their interpretation.

\section{REMEDIES}

When a tribunal finds a host state to be in breach of its obligations under a IIA, the tribunal must move to the question of remedies. The applicable law may address the question of remedies but the IIAs themselves are usually silent on the matter. However, some treaties such as NAFTA and the ECT, do limit available remedies to monetary damages and restitution. ${ }^{175}$ There are no such limitations in the procedural rules of the ICSID or

171 Ibid at para 234. At paras 221-28 the majority canvassed the following Awards: Azurix, supra note 40; Siemens, Award, supra note 61; CMS, Annulment Proceeding, supra note 18. Arbitrator Orrego Vicuňa offered a vigorous dissent suggesting that to confine the benefit of the obligation to the actual party to the contract will negate the protection offered by the umbrella clause especially in those cases in which the use of local companies is "required by the host State by means of legislation or regulation" (see Burlington, Dissent, supra note 118 at para 9).

172 See e.g. Fedax NV v Venezuela (1998), Case No ARB/96/3 (ICSID), Award at para 29; SGS Société Générale de Surveillance SAv Republic of the Philippines (2004), Case No ARB/02/6 (ICSID), Decision on Jurisdiction paras 127-28. See also Duke Energy Electroquil Partners \& Electroquil SA v Republic of Ecuador (2008), Case No ARB/04/19 (ICSID), Award at para 325.

173 SGS Société Générale de Surveillance SA v Islamic Republic of Pakistan (2003), Case No ARB/01/13 (ICSID), Decision on Jurisdiction at para 166; LG\&E, supra note 22 at para 175.

174 CMS, Award, supra note 92 at paras 299-300; Pan American Energy LLC \& BP Argentina Exploration Company v Argentine Republic (2006), Case No ARB/03/13 (ICSID), Decision on Preliminary Objections at paras 108-109; El Paso Energy Company v Argentine Republic (2006), Case No ARB/03/15 (ICSID), Decision on Jurisdiction at paras 79-81.

$175 \quad$ NAFTA, supra note 3, art 1135 ("Where a Tribunal makes a final award against a Party, the Tribunal may award, separately or in combination, only: (a) monetary damages and any applicable interest; (b) restitution of property, in which case the award shall provide that the disputing Party may pay monetary damages and any applicable interest in lieu of restitution”); ECT, supra note 5, art 26(8)) (“An award of arbitration concerning a measure of a sub-national government or authority of the disputing Contracting Party shall provide that the Contracting Party may pay monetary damages in lieu of any other remedy granted.”). 
UNCITRAL arbitral forums. ${ }^{176}$ The remedies available to an investor may also be restricted by the terms of an investment contract. In the absence of such limitations, arbitral tribunals look to principles of general international law in exercising their remedial powers.

It is a well-established principle in international law that a state responsible for an internationally wrongful act (for example, a breach of any of the disciplines discussed above) is obligated to make "reparation" for that act. The concept of reparation in international law captures a number of possible remedies including restitution, compensation, and satisfaction. ${ }^{177}$ In investment arbitration, reparation made to investors for breaches of IIAs almost always comes in the form of compensation. However, non-pecuniary remedies like restitution (that is, specific performance or an injunction) are part of the spectrum of remedies available to foreign investors. To date, investors have not used satisfaction (or an apology, or declaration of wrongfulness) as a form of reparation. ${ }^{178}$ As a result, the discussion below focuses on restitution and compensation as the dominant forms of reparation available to investors.

\section{A. Restitution}

The availability of restitution as a form of reparation is widely accepted in international law. It consists of restoring the status quo ante (that is, placing the claimant in the position it was in prior to the commission of the internationally wrongful act). ${ }^{179}$ Restitution is the preferred method of reparation in international law. ${ }^{180}$ The ILC's draft articles on the law of state responsibility indicate that restitution should be awarded "provided and to the extent that" it is not "materially impossible," and that it does not place a disproportionate burden on the state responsible for the internationally wrongful act when compared with the possible benefit to the injured state. ${ }^{181}$ Thus, if an order for restitution does not satisfy the requirement for full reparation, restitution may be awarded in conjunction with compensation or satisfaction.

ICSID Convention, supra note 11, art 48. Article 54 provides for the enforcement of only pecuniary obligations imposed on a Contracting state by virtue of an arbitral award. However, this does not prohibit tribunals from imposing non-pecuniary obligations. See Christoph Schreuer, "Non-Pecuniary Remedies in ICSID Arbitration” (2004) 20:4 Arbitration International 325 at 326-27. See also UNCITRAL, UNCITRAL Arbitration Rules (as revised in 2010), GA Res No 65/22 UNCITRAL, 2010, Supp No 17 UN Doc A/65/465, art 34.

177 See Report, supra note 7, arts 34-37.

178 Satisfaction, in the form of a declaration of wrongfulness was awarded as a form of reparation for moral damages suffered by Turkey in two cases. The investors in both cases commenced arbitral proceedings against Turkey for alleged breaches of the ECT. The investors asserted standing to initiate those proceedings on the basis of their shareholdings in Turkish electricity companies which saw their concession agreements with the Turkish Ministry of Energy terminated in 2003. When the investors could not produce evidence about when they acquired their ownership interests, arbitral tribunals in both instances dismissed their respective cases and found that the investors' claims in each case were manifestly ill-founded and amounted to an abuse of process (see Europe Cement Investment \& Trade SA v Turkey (2009), Case No ARB(AF)/07/2 (ICSID), Award; Cementownia 'Nowa Hut' SA v Turkey (2009), Case No ARB(AF)/06/2 (ICSID), Award). For arguments supporting the proposition that satisfaction can only be used as a form of reparation for damages suffered by a state (not an individual or corporation) see Patrick Dumberry, "Satisfaction as a Form of Reparation for Moral Damages Suffered by Investors and Respondent States in Investor-State Arbitration Disputes” (2012) 3:1 Journal of International Dispute Settlement 205.

Ibid.

Report, supra note 7, art 35. 
In international investment law, restitution is rarely ordered. This may have more to do with the way in which claims are initiated by investors and the circumstances in which investment disputes arise rather than any limitation based on the jurisdiction of arbitral tribunals. Consider, for example, the OEPC II case. After obtaining a \$75 million award in its favour over unpaid value-added tax refunds, ${ }^{182}$ Occidental Petroleum Corporation and its corporate affiliate found themselves embroiled in another dispute with Ecuador. ${ }^{183}$ This time Ecuadorian government officials, amidst mounting political pressure, terminated the claimants' participation contract on the grounds that OEPC had unlawfully entered into a farmout agreement with an AEC subsidiary without first obtaining state consent. After terminating the contract, government officials arrived at the claimants' offices in Quito and seized all of its property. Subsequently, officials and the Ecuadorian National Police took physical possession of the claimants' oil fields, including wells, drills, and storage facilities. In the wake of these actions, the claimants initiated arbitration proceedings claiming damages for the losses it had suffered. ${ }^{184}$ In these circumstances, restitution is hardly a plausible, let alone an available, remedy. Thus in the case of OEPC II, compensation may have been the only appropriate form of reparation.

However, there are circumstances in which restitution may be an appropriate remedy to consider - especially if a foreign investor wishes to continue operating within a host state and the circumstances of the dispute permit such a possibility. In such cases, tribunals have indicated their willingness to make orders of specific performance. One such example is $N y k o m b$, a case already addressed above in relation to discrimination and national treatment. After finding that Latvia had favoured domestic co-generation facilities by purchasing electricity at higher rates than those provided to the Swedish claimant, the Tribunal awarded the Swedish investor damages for its losses up to the date of the award. More significantly for this discussion, however, was the Tribunal's order requiring Latvia to honour its contractual obligations with the Swedish investor and pay the higher price for delivered electricity going forward until the end of the contractual term. ${ }^{185}$

In addition to preserving the investment relationship between an investor and a host state, there may be strategic rationales for including remedies like specific performance or an injunction in a prayer for relief. This may, for example, bolster a foreign investor's application for provisional measures or interim relief during an investor-state arbitration. Although investor-state arbitral tribunals have the power to grant provisional measures, this remains exceptional. Tribunals are strict in requiring investors to establish that provisional measures are necessary to ensure that they will suffer urgent and irreparable harm. ${ }^{186}$ One of the hurdles faced by investors seeking such relief is that their claims are often only for monetary relief. This may make it difficult to argue irreparable harm at the interim stage of

OEPC I, supra note 43

OEPC II, supra note 103.

Ibid at paras $173-200$.

See Nykomb, supra note 54 at 5.2. See also, Enron Corporation and Ponderosa Assets, LP v Argentine Republic (2004), Case No ARB/01/3 (ICSID), Decision on Jurisdiction at para 79 (the Tribunal found that it had the power to order restitutive remedies such as specific performance or an injunction).

See e.g. Plama Consortium Limited v Republic of Bulgaria (2005), Case No ARB/03/24 (ICSID), Order at para 38 . 
arbitral proceedings. ${ }^{187}$ One way for an investor to bolster its chances of obtaining interim relief and thereby preserve its investment in a host state is to plead forms of restitution from the outset.

\section{B. COMPENSATION}

Compensation is the appropriate reparation measure whenever restitution in integrum is not possible. ${ }^{188}$ The only limitation to compensation as the appropriate form of reparation is that the damage needs to be "financially assessable." 189 Included within this definition are material (for example, damages to property) and moral (for example, individual pain and suffering) damages resulting from an internationally wrongful act. ${ }^{190}$ Like restitution, awards of compensation must "re-establish the situation which would, in all probability, have existed" prior to the commission of the internationally wrongful act. ${ }^{191}$ As a result, monetary reparation in the broader context of international law, and in international investment law more specifically, must reflect the damage actually suffered by the victim of the internationally wrongful conduct.

In contrast to general public international law, which emphasizes the secondary nature of compensation as a form of reparation, compensation is the primary form of reparation in international investment law. As noted above, this is likely because cases brought before investor-state arbitral tribunals typically involve situations in which the investment relationship between an investor and a host state has broken down. In such circumstances, a monetary award is preferable. In addition, some IIAs expressly give preference to monetary awards. ${ }^{192}$ The calculation of such awards can be a complex undertaking with different causes of action under an IIA resulting in different approaches to compensation. ${ }^{193}$ Added to such complexities are recent arbitral awards addressing moral damages, which have led

In OEPC II, supra note 103, the claimants made two requests for provisional measures. The first request asked the Tribunal to require Ecuador's national oil company (Petroecuador) to notify the claimants of any potential contractual arrangements Petroecuador was considering with third parties that related to operations on the same lands the claimants originally had an interest in by virtue of its participation contract with Petroecuador. The second request asked the Tribunal to require Petroecuador to enter into a contractual arrangement with the claimants for the shipment of 42,000 barrels per day of crude on the claimants' unused reserved capacity at a specified tariff. The tribunal rejected both of these requests. One of the reasons given for this decision was the fact that the claimant would not suffer irreparable harm. Any damage suffered as a result of Ecuador's actions could be financially assessed and compensated for in a final award (See Occidental Petroleum Corporation and Occidental Exploration and Production Company v Republic of Ecuador (2007), Case No ARB/06/11 (ICSID), Decision on Provisional Measures).

Reports, supra note 7, art 36(1) provides that “[t]he state responsible for an internationally wrongful act is under an obligation to compensate for the damage caused thereby, insofar as such damage is not made good by restitution.”

Ibid, art 36(2) provides that " [t]he compensation shall cover any financially assessable damage including loss of profits insofar as it is established."

See James Crawford, “The ILC’s Articles on Responsibility of States for Internationally Wrongful Acts: A Retrospect,” online: American Society of International Law <http://www.asil.org/ajil/ilcsymp7.pdf>. Chorzów, supra note 179 at para 125.

See e.g. ECT, supra note 5, art 26(8); NAFTA, supra note 3, art 1135(1).

A review of the arguments raised by investors on the issue of damages is often illustrative of the complexities associated with awards of compensation in the context of different causes of action. See e.g. PSEG Global, supra note 45 at paras 281-92 (where in the context of frustrated negotiations over a proposed BOT project to construct a new thermal base load power plant, the claimants raised three arguments on damages. On the assumption that there was expropriation of their investment, the claimants sought US\$114.951 million, the fair market value of their investment as on the date of expropriation. Alternatively, the claimants sought US\$223.742 million in profits that they would have obtained under their concession contract. Finally, at a bare minimum, the claimants sought to recoup costs associated with establishing their investment). 
to confusion about whether such damages are compensatory or punitive and how they should be assessed. ${ }^{194}$ Moreover, there is an emerging concern that the quantum of compensation awarded to investors in some cases may be overly burdensome for host states, a result which may have consequences for international investment law as a whole. ${ }^{195} \mathrm{~A}$ thorough examination of all of these issues, while useful, is outside the scope of this article. As a result, the discussion that follows highlights some of the key issues regarding awards of compensation in cases involving: (1) an expropriation; and those involving (2) breaches of treaty provisions unrelated to expropriations.

\section{COMPENSATION IN EXPROPRIATION CASES}

In theory there is a distinction between compensation owed to an investor for a lawful expropriation and reparation owed for an unlawful expropriation. ${ }^{196}$ In practice, however, tribunals typically make an award for an investment's fair market value, regardless of the type of expropriation. ${ }^{197}$ Thus, compensation for expropriation is an objective standard that ideally looks to the amount a willing buyer would normally pay to a willing seller in an arm's length transaction. That task is relatively easy if there is an active market for the type of asset concerned (for example, land). When the investment is a going concern for which a flow of profits is expected, such as a long-term concession, the valuation exercise is more complex and often requires consideration of the future prospects or earning capacity of the investment. ${ }^{198}$ Many different techniques can be used in order to estimate the value of an investment, and there is no single valuation method that suits all circumstances or all investments. ${ }^{199}$

See e.g. Desert Line Projects LLC v The Republic of Yemen (2008), Case No ARB/05/17 (ICSID), Award (where the Tribunal awarded the claimant US $\$ 1$ million for moral damages after the claimant was forced into an unfavourable settlement of a prior arbitral award by the Yemen government, and its employees were physically threatened, arrested and detained in the process); Joseph Charles Lemire v Ukraine (2011), Case No ARB/06/18 (ICSID), Award (where the Tribunal rejected the claimant's plea for US\$3 million in moral damages and found that moral damages may only be awarded where the host state has subjected an investor to grave physical duress or its equivalent and caused the investor to experience mental suffering or loss of reputation). For a review of the jurisprudence in this area see Jarrod Wong, "The Misapprehension of Moral Damages in Investor-State Arbitration” in Arthur Rovine, ed, Contemporary Issues In International Arbitration And Mediation: The Fordham Papers 2012 [Leiden, Martinus Nijhoff, forthcoming in 2013].

See e.g. Margaret B Devaney, "Remedies in Investor-State Arbitration: A Public Interest Perspective" (22 March 2013) online: International Institute for Sustainable Development <http://www.iisd.org/ itn/2013/03/22/remedies-in-investor-state-arbitration-a-public-interest-perspective/> .

See Sergey Ripinisky \& Kevin Williams, Damages in International Investment Law (London: British Institute of International and Comparative Law, 2008) at 64-88 (the authors examine the varying approaches used to determine compensation in the context of unlawful and lawful expropriations and note that compensation for lawful expropriations is tied to the fair market value of the investment taken while unlawful expropriations may permit an investor to recover losses greater than the fair market value of its investment. In the latter case, an investor may be compensated for the post-expropriation increase in value of the investment or for post-expropriation incidental expenses (i.e. costs of maintaining bare bones operations of the investor's subsidiary in the host state)). Ibid at 88.

Dolzer \& Schreuer, supra note 50 at 274-75.

See Ripinsky \& Williams, supra note 196 at 181-261 examining the subject of investment valuation in the context of investor-state disputes. The World Bank has also provided a useful description of the primary valuation methods as well as the circumstances in which a particular method is likely to be relevant (see World Bank, Legal Framework for the Treatment of Foreign Investment Volume II Guidelines (1992), online: World Bank <http://www-wds.worldbank.org/servlet/WDSContentServer/ WDSP/IB/1999/11/10/000094946_99090805303082/Rendered/PDF/multi_page.pdf> [World Bank Guidelines]. 
The most controversial valuation method within the expropriation context has been the discounted cash flow (DCF) method. The DCF method looks prospectively at an investment's expected future income and assumes that its potential earning capacity is a good proxy for the price a hypothetical buyer would be willing to pay for the investment. In order to calculate the present value of future cash flows, a discount factor has to be applied in order to take account of the time value of money and risk. ${ }^{200}$ The ILC's Draft Articles on State Responsibility preclude compensation for speculative or uncertain damage, which leads to difficulties when investors ask arbitrators to accept the DCF method in expropriation cases. ${ }^{201}$

Given that the DCF method always implies projections of cash flows into the future, some investors have had difficulty convincing arbitral tribunals to adopt this valuation method for evidentiary reasons. For example, in Compañía de Aguas del Aconquija S.A. and Vivendi Universal S.A. v. Argentine Republic ${ }^{202}$ the Tribunal held that the claimant had failed to establish with a sufficient degree of certainty that its expropriated concession for the provision of water and sewage services would have been profitable and therefore rejected the DCF method as the appropriate way to assess damages. ${ }^{203}$ However, tribunals have applied the DCF method in other expropriation cases. For example, in ADC Affiliate Limited and ADC \& ADMC Management Limited $v$. The Republic of Hungary, ${ }^{204}$ the Tribunal found that Hungary had unlawfully expropriated the claimants' investment in the Budapest-Ferihegy International Airport. The Tribunal applied the DCF in estimating the fair market value of that investment although without a detailed explanation. ${ }^{205}$ Thus, arbitral practice reveals that the appropriateness of a particular method is largely determined by the circumstances surrounding the investment at issue and the information available with respect to that investment. In determining an appropriate quantum of damages in expropriation cases, investor-state arbitral tribunals rely, therefore, on the characteristics of the investment, such as its proven track record of profitable operations and the available market references.

\section{COMPENSATION FOR BREACHES OF TREATY PROVISIONS UNRELATED TO EXPROPRIATION}

In the past, most investment disputes involved expropriations. However, as evidenced by the discussion in Part V, a growing number of cases engage other investment treaty provisions, such as the FET, NT, and Full Protection and Security standards. Arbitral tribunals confronted with non-expropriation violations have usually referred to the general principle that a claimant should be fully compensated (that is, put in a position that would have existed but for the breach) for the loss suffered as a result of such violations. ${ }^{206}$ That

For a definition of the discounted cash flow method of valuation see World Bank Guidelines, ibid at 42. Report, supra note 7, art 36(2).

Compañía de Aguas del Aconquija SA and Vivendi Universal SA v Argentine Republic (2007), Case No ARB/97/3 (ICSID), Award [Vivendi II].

Ibid; Metalclad Corporation v United Mexican States (2000), Case No ARB/(AF)/97/1 (ICSID), Award at para 120. See also Tecmed, supra note 121; Siemens, Award, supra note 61; Waguih Elie George Siag and Clorinda Vecchi v Arab Republic of Egypt (2009), Case No ARB/05/15 (ICSID), Award.

ADC Affiliate Limited and ADC \& ADMC Management Limited v Republic of Hungary (2006), Case No ARB/03/16 (ICSID), Award of the Tribunal.

Ibid at paras 423-44, 502-503; CMS, Award, supra note 92; CME v Czech Republic, UNCITRAL, Final Award (14 March 2003).

See e.g. Petrobart, supra note 86 at 78 (the Tribunal held that the award of damages should place the claimant, so far as possible, in the financial position it would have found itself in had the breaches not occurred). 
general principle does not, however, address how such damages should be calculated. This task necessarily relies upon a number of different factors, such as the interest affected, the nature and extent of the loss, whether the investment has been destroyed or impaired, and whether the investment was a fully operational enterprise or still in preliminary phases of operation. ${ }^{207}$ The discussion below highlights some of the ways in which arbitral tribunals have calculated damages in the energy sector using these criteria. In addition to these criteria the examination below features a recent arbitral decision, which has, for better or worse, incorporated the tort law principle of contributory negligence into its damage calculation.

\section{a. Diminution in the Investment's Value}

In circumstances where unlawful conduct has resulted in a significant devaluation of an investment, arbitrators have assessed compensation by measuring the decrease in the fair market value of the investment. This approach to calculating damages has been used by some tribunals deciding cases in the context of Argentina's 2001 financial crisis. ${ }^{208}$ In El Paso, the Tribunal found that the cumulative effect of Argentina's measures constituted a breach of the FET standard and caused a decrease in the value of the claimant's shareholdings in companies operating within Argentina's electricity and hydrocarbon sectors. ${ }^{209}$ In the absence of relevant guidance from the applicable US-Argentina BIT on the matter of compensation in non-expropriation cases, the Tribunal noted that many cases involving Argentina have held that damages in such cases should compensate for the difference in the value of the investment resulting from the treaty breach. The Tribunal adopted the same approach. ${ }^{210}$ Relying on its own appointed expert, the Tribunal determined the market value of El Paso's investment with and without Argentina's measures and awarded El Paso the difference between the two - approximately US\$40 million. ${ }^{211}$

\section{b. Loss of Dividend by Shareholder}

In contrast to this approach, tribunals in other cases involving the 2001 Argentine financial crisis have calculated damages by considering the actual loss suffered by the investor. In such instances, tribunals have referenced the amount of dividends lost by shareholders as a result of the host state's unlawful conduct. One such example is $L G \& E$, a case in which the Tribunal found that measures taken by Argentina (changes to the tariff scheme for gas distribution companies) that had violated the FET standard, were discriminatory and breached the umbrella clause of the relevant US-Argentina BIT resulting in a decrease in the amount of dividends distributed to shareholders. ${ }^{212}$ Importantly, the Tribunal found that Argentina was in a state of necessity between 1 December 2001 and 26 April 2003 and,

H Weisburg \& C Ryan, "Means to Be Made Whole: Damages in the Context of International Investment Arbitration” in Yves Derains \& Richard H Kreindler, eds, Evaluation of Damages in International Arbitration (Paris: International Chamber of Commerce, 2006) 165 at 169-70. See also Thomas W Wälde \& Borzu Sabahi, "Compensation, Damages, and Valuation” in Muchlinski, The Oxford Handbook, supra note 125 at 1049.

208 See e.g. CMS, Award, supra note 92; Enron, Award, supra note 41; Sempra, supra note 41; BG Group PLC, supra note 116 .

El Paso, supra note 46 at paras 507, 517, 684.

Ibid at paras 700-705.

Ibid at paras 698-742.

LG\&E, supra note 22 at paras 132-39, 147-48, 169-75. 
therefore, should be absolved from international responsibility for losses that occurred during this period. ${ }^{213}$

In determining the amount of compensation owed to the claimants, the Tribunal rejected the "fair market value" approach of awarding the diminution of the investment's market values before and after the date of a host state's treaty breaches. ${ }^{214}$ Distinguishing this case from those such as El Paso where the claimants sold their interests in Argentina's electricity and hydrocarbon sector, the Tribunal reasoned that the claimants in this case remained in possession of their shares, which could rebound in value in the future. ${ }^{215}$ As a result, the Tribunal determined that the "actual loss" suffered by the claimants was the reduction in the amount of dividends paid out to the claimants caused by Argentina's wrongful conduct. To calculate compensation, the Tribunal assessed "the amount of dividends that could have been received but for the adoption of the measures" by comparing the pre-crisis dividends with the dividends actually paid out after the crisis. ${ }^{216}$

\section{c. Failure to Reimburse Taxes or to Pay the Contract Price}

Tribunals have found other ways of compensating investors for the losses they have suffered, especially when such losses are purely monetary in nature and do not require a full valuation of the overall investment. For example, in OEPC I the Tribunal found that Ecuador's refusal to reimburse sums of Value-Added Tax paid by the investor breached the NT, FET, and full protection and security standards in the US-Ecuador BIT. ${ }^{217}$ As compensation, the Tribunal awarded the amounts of VAT paid by Occidental and not refunded by Ecuador. ${ }^{218} \mathrm{~A}$ similar approach has been adopted in cases where the loss suffered was in the form of unpaid contract prices. For example, in Nykomb the Tribunal found that Latvia discriminated against the Swedish claimant when it paid a higher price to Latvian companies for electricity than it paid to the claimant's Latvian subsidiary. ${ }^{219}$ In that case, the Tribunal based its damages calculation on the difference between the price to Latvian companies and the Swedish claimant for past electricity supplies and, as discussed above, ordered specific performance for the amounts owing for the remaining term of the claimant's electricity supply contract with Latvia. ${ }^{220}$

\section{d. Loss of Invested Amounts}

In cases where an investment project is in the early phases of development and is halted due to a host state's unlawful conduct, tribunals have awarded compensation based on the amounts invested by the investor. In PSEG Global, a US company, relying on contracts

Ibid at paras 226-65.

Ibid at paras 35-38.

Ibid at para 47.

Ibid at para 48 .

OEPC I, supra note 43.

Ibid at paras 203-208.

Nykomb, supra note 54 at para 38.

Ibid at paras 38-39. See also Petrobart, supra note 86 at paras 82-84 (as a result of government interference the claimant was not paid for deliveries of natural gas in accordance with its contract with a state enterprise. This, according to the Tribunal, breached the ECT, and in the award the state was ordered to pay amounts owed to the investor under the contract. That amount was reduced by 25 percent because the Tribunal reasoned that there was no complete certainty that the investor would have been able to recover the full amounts owing). 
concluded with Turkey, invested in a feasibility study and other preparatory documents with a view to building a power plant and an adjacent coal mine. ${ }^{221}$ Subsequently, the Turkish government took a number of actions that were found to have violated the FET standard in the Turkey-US BIT, which resulted in the termination of the claimants' investment at an early stage. ${ }^{222}$ The claimants presented alternative damage calculations, including one based on the fair market value of the investment. ${ }^{223}$ In rejecting this approach to damages, the Tribunal distinguished this case from those instances of non-expropriatory treaty breaches where compensation was assessed by calculating the FMV of the investment involved. Specifically, the Tribunal observed that in the latter types of cases, damage to the investments occurred when the investment was more advanced (that is, in production), not merely in the planning or negotiation stage. ${ }^{224}$ As a result, the tribunal calculated compensation on the basis of expenses incurred by the investor in connection with the investment project. ${ }^{225}$

\section{e. $\quad$ Future Losses}

There is some discussion in the jurisprudence as to whether a tribunal has the jurisdiction to award damages for future losses as well as for losses that have already occurred. Some tribunals have been more skeptical than others on this issue. In $L G \& E$ the claimant attempted to obtain damages for future losses. ${ }^{226}$ In particular, the claimants argued that changes made to Argentina's tariff scheme for gas distribution companies continued to violate the USArgentina BIT and that they should be compensated for future lost dividends. ${ }^{227}$ While the Tribunal agreed that Argentina's measures continued to violate its treaty obligations, it did not allow the claimants to recover for future losses. Specifically, the Tribunal found that such losses were too speculative as it was not certain that the claimants would continue to incur the same level of losses in the future. ${ }^{228}$ As a result, the Tribunal acknowledged that the claimants were entitled to bring further action against Argentina should they continue to suffer damages by virtue of Argentina's continuing treaty breach. ${ }^{229}$

Recovery for future losses was also an issue in Mobil. ${ }^{230}$ The majority of the Tribunal took the view that in principle it could award damages for losses that flow from a breach which began in the past but which continues into the future. In this case, the two investors claimed damages based on the incremental expenditures they would be required to make under the new guidelines on domestic performance requirements in comparison with what they would have been required to spend under their benefit plans. However, in the end, the majority found it impossible to make any award, not because the damages were speculative, but because the actual calculation of damages depended on far too many variables that could not be ascertained at the time of the award. The result would seem to be installment litigation. ${ }^{231}$

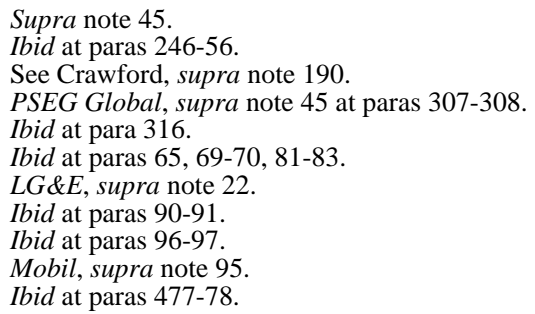


Thus, regardless of a tribunal's willingness to award such relief, in practice investors have difficulty successfully obtaining compensation for future losses.

\section{f. Allocating Responsibility}

In addition to awarding damages based on the parameters outlined above, tribunals will reduce such awards in certain cases and thereby allocate responsibility between governments and foreign investors for failed investment projects. ${ }^{232}$ The recent decision in OEPC II illustrates that such decisions are not without controversy. Having found Ecuador liable to the claimant for expropriating its investment and violating the FET standard, the Tribunal decided to assess damages in this case by calculating the fair market value of the claimants' participation contract as of the date of the Caducidad Decree. ${ }^{233}$ The Tribunal reduced the amount of damages owed to the claimants, however, because of the negligence of the claimant (that is, for violating Ecuadorian law by entering into the farmout agreement without ministerial authorization). Accordingly, the majority of the Tribunal reduced the claimants' damage amount by 25 percent, an estimation of the claimants' contribution to the prejudice it suffered when Ecuador issued the Caducidad Decree. ${ }^{234}$

Ecuador attempted to have the damage award reduced even further by asking the Tribunal to consider the impact of a number of factors, including the farmout agreement, on the quantum of the award. ${ }^{235}$ Having transferred 40 percent of its interest under the participation contract to AEC, Ecuador argued that a ceiling should be placed on the quantum of damages available to the claimants. In particular, Ecuador contended that the claimants were only entitled to damages equal to its 60 percent interest under the participation contract (as amended by the farmout agreement). ${ }^{236}$ The majority of the Tribunal rejected this argument, however, and reasoned that the assignment of rights under the participation contract pursuant to the farmout agreement was null and void because it lacked ministerial authorization, as required by Ecuadorian law. Thus, no reduction based on the assignment was possible. ${ }^{237}$ Applying these findings, the majority of the Tribunal awarded the claimants US\$1.77 billion plus interest, one of the largest awards in ICSID's history. ${ }^{238}$

On 11 October 2012, a few days after the Tribunal issued its award, Ecuador filed a request for annulment of the award. Whatever the result of the annulment proceedings, the

See e.g. MTD Equity Sdn Bhd \& MTD Chile SA v Republic of Chile (2004), Case No ARB/01/7 (ICSID), Award at paras 242-43; MTD Equity Sdn Bhd \& MTD Chile SA v Republic of Chile (2007), Case No ARB/01/7 (ICSID), Decision on Annulment at para 101 (the Tribunal and the ad hoc committee held that the investors had made decisions that needlessly heightened their risks and for which they bore responsibility. As a result damages were reduced by 50 percent). See also Bogdanov, supra note 12 at 19.

233 OEPC II, supra note 103 at paras 452-55.

$234 \quad$ Ibid at para 687.

235 Ibid at paras 467-74, 550-51, 571-74, 659-60.

$236 \quad$ Ibid at paras 572-74.

$237 \quad$ Ibid at paras 612-58.

238 Ibid at paras 825, 848. This damages calculation was the subject of a dissenting opinion, which took issue with numerous aspects of the majority's reasoning. The dissent raises questions about the majority's allocation of responsibility in the form of a 75/25 split. The focus of the dissent, however, is on the majority's decision to consider the assignment of interests under the farmout agreement null and void. In particular, the dissent reasons that without a competent court declaration invalidating the farmout agreement, it remained in force and binding - a finding that would therefore limit the damages available to OEPC to its 60 percent interest under the participation contract (see Occidental Petroleum Corporation v Republic of Ecuador (2012), Case No ARB/06/11 (ICSID), Dissent). 
OPEC II award demonstrates the complexities associated with quantifying the appropriate amount of compensation in investor-state disputes. While tribunals routinely allocate responsibility between host states and foreign investors for failed investment projects, the impact of different variables affecting how such allocations occur in any given case can be controversial and will be determined on a case-by-case basis.

These awards reveal that tribunals use a variety of methodologies to calculate the compensation owed to an investor when a host state breaches its treaty obligations. ${ }^{239}$ Consequently, it would be inaccurate to think that awards of compensation are determined on the basis of a uniform approach, especially given the variety of factual circumstances and types of loss that can occur with respect to complex international investments.

\section{CONCLUSION}

As noted in the introduction to this article, foreign investors in the energy sector have long sought to secure guarantees from the host state in an attempt to reduce the future risk that the host state might unilaterally take measures that negatively impact their investments. The various disciplines of IIAs aim to meet this need. However, both in the context of the energy sector and beyond, the interpretive jurisprudence in relation to IIAs is still developing with the result that there is some continuing uncertainty with respect to the scope of the protections afforded by IIAs. In this article, we have identified four main areas of uncertainty where arbitral tribunals have reached quite disparate conclusions. The first relates to the national treatment standard and in particular the question of how the comparator is selected for the purposes of assessing whether there is discriminatory treatment. The second relates to the construction and interpretation of the FET standard. As to the construction of the standard the principal issue here is whether the text seeks to confine the scope of the clause to the minimum standard of treatment in international law or whether the text refers more generally to "fair and equitable treatment." The interpretive question that follows is whether the terms fair and equitable should be accorded a plain meaning or a technical meaning that effectively takes the interpreter back to the minimum standard of treatment. The third area of uncertainty deals with the scope of the MFN discipline and in particular the question of whether or not an investor can use the MFN principle to take advantage of more favourable dispute resolution procedures than those found in the subject treaty. And the final area of radical divergence in the jurisprudence relates to the proper construction of the umbrella clause of the treaty. Here, the divergence is apparently between those who seek to give the clause its ordinary meaning (which inevitably casts the scope of the discipline broadly) and those who rely on various strategems (including privity) to limit the scope of the clause for fear of internationalizing disputes which, as between private parties would simply be litigated in the domestic courts.

An overarching theme which explains at least some of the divergent opinions that we see is the tension between protection of investor interests and the need to take account of the interests of the host state in regulating industries in the public interest. One recent response 
to this tension has been the resort by some arbitral tribunals to ideas of reasonableness and proportionality in applying core IIA disciplines (for example, FET and the duty not to expropriate). By contrast, in other cases such as Murphy (dealing with host state treaty reservations) the Tribunal seems to have gone out of its way to reduce the regulatory space afforded host states. Consequently, it is imperative that current and prospective foreign investors in the energy sector remain aware of how this balance is being struck and re-struck in relation to their applicable IIA in order to make informed assessments of the their investment's legal risk.

In addition to the ever-changing case law on the core disciplines within IIAs, the remedies available to investors are a topic of increasing importance to foreign investors in the energy sector. Despite the availability of compensatory relief, there are circumstances in which nonpecuniary remedies, such as restitution, may better serve an investor's interests (for example, where the investor has a desire to continue operating within a host state or seek injunctive relief). Nonetheless, compensation has been, and will undoubtedly continue to be, the primary remedy awarded to investors in cases in which a host state breaches its treaty obligations. As the jurisprudence illustrates, determining the appropriate quantum of such awards is complicated. Given the variety of factual circumstances and the types of loss that can occur in relation to complex international investments, especially those in the energy sector, tribunals use a variety of methodologies to calculate the compensation owed to an investor when a host state breaches its treaty obligations.

Thus, in relation to remedies (particularly compensation) the international investment law regime appears malleable enough to respond to an investor's particular circumstances and the facts of any given case. However, that same flexibility leads to uncertainties with respect to the protection afforded investors in this regime (that is, the value of the investment protected) both at the time of investment and in the future when such protection may be relied upon. Until such time that there is more certainty regarding remedies in the international investment law regime, especially in relation to the calculation of damages, foreign investors are well advised to factor in such risk when evaluating investments in the energy sector and the protections actually afforded by different IIAs. 